\title{
Realigning the Governmental/Proprietary Distinction in Municipal Law
}

\author{
Hugh D. Spitzer*
}

\begin{abstract}
CONTENTS
INTRODUCTION

I. DOCTRINAL AREAS USING THE GOVERNMENTAL/PROPRIETARY

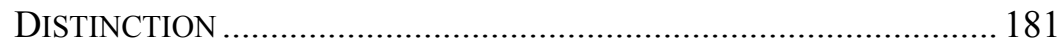

A. Legislative Grants of Municipal Authority .............................. 181

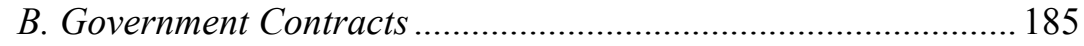

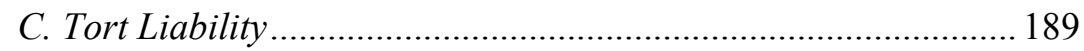

1. Sovereign Immunity .................................................. 189

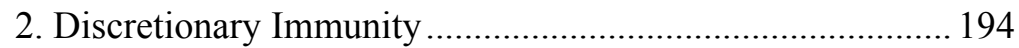

3. Public Duty Doctrine .......................................................... 195

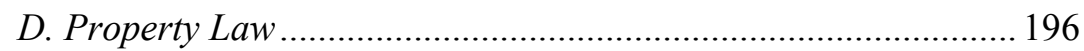

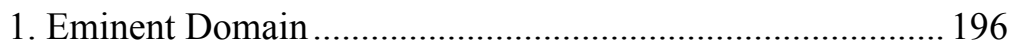

2. Adverse Possession........................................................... 198

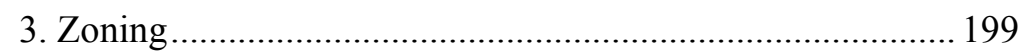

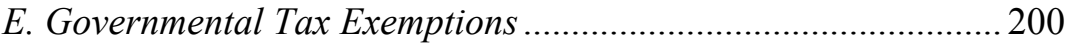

F. Mindless Application of Labels.............................................. 202

II. BACK TO THE FUTURE: A COMPREHENSIVE REALIGNMENT OF THE

GOVERNMENTAL/PROPRIETARY DISTINCTION............................204

III. APPLYING THE REALIGNED CATEGORIES TO DOCTRINAL AREAS

WHERE THE GOVERNMENTAL/PROPRIETARY DISTINCTION HAS

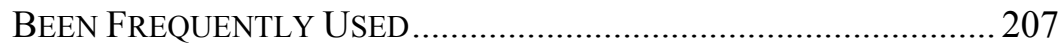

\footnotetext{
* Professor of Law (Acting), University of Washington. B.A. 1970, Yale University; J.D. 1974, University of Washington; LL.M. 1982, University of California at Berkeley. The views expressed in this article are solely the author's and do not reflect the views of any client of the firm with which he practices municipal law on a part-time basis. The author thanks Janice C. Griffith, William Fosbre, and P. Stephen DiJulio for their insightful comments and suggestions. Thanks also to Alyssa Halstrom and Nathan Barnes for their research assistance, and Alena Wolotira for her technical editing.
} 
A. Applying the Realigned Groupings to Legislative Grants of Municipal Authority

B. Applying the Realigned Groupings to Government Contracts and "Contracting Away" Inalienable Governmental Rights and Duties 209

C. Applying the Realigned Groupings to Tort Liability 210

D. Applying the Realigned Groupings to Property Law 212

E. Applying the Realigned Groupings to Taxation and Tax

Exemptions.

CONCLUSION 214

\begin{abstract}
Lawyers and judges who deal with municipal law are perpetually puzzled by the distinction between "governmental" and "proprietary" powers of local governments. The distinction is murky, inconsistent between jurisdictions, inconsistent within jurisdictions, and of limited use in predicting how courts will rule. Critics have launched convincing attacks on the division of municipal powers into these two categories. Most articles have focused on problems with the distinction in specific areas of municipal law. In contrast, this article provides a comprehensive analysis of the governmental/proprietary distinction in seven specific doctrinal areas: legislative grants of municipal authority, government contracts, torts, eminent domain, adverse possession, zoning, and taxation. The article concludes that confusion with the governmental/proprietary distinction will be materially reduced if local government powers are conceptually realigned. Instead of completely jettisoning the distinction, as some have proposed, the "governmental" category should be split in two, with coercive and policymaking powers like the police power, law enforcement, and the powers of taxation, eminent domain and budgeting constituting a "governmental sovereign powers" category. General services that economists call public goods should be detached from the governmental sovereign powers and regrouped with proprietary services like municipal utilities to create a category of "governmental service activities." The article evaluates the new groupings within the context of each of seven substantive areas of law where the governmental/proprietary distinction has been used. The article concludes that realigning local government powers will reduce analytical confusion and help legislators and judges when they make key choices in both the lawmaking and litigation context.
\end{abstract}




\section{INTRODUCTION}

The classification of local government powers into "governmental" and "proprietary" categories causes more confusion than perhaps any other distinction in municipal law. The topic is infrequently addressed in academic journals because of the morass of conflicting and seemingly irreconcilable cases and outcomes. The most commonly used treatise in the field states that whether a municipal corporation is acting in its "governmental" or in its "proprietary" (a/k/a "private") capacity, "is often a difficult question to answer, and there is a considerable conflict in the decisions of the courts respecting the class to which certain functions or powers belong.... No hard and fast rule satisfactorily distinguishing the one capacity from the other for general application has been announced." A 1936 law review article by the former Cincinnati mayor and law professor Murray Seasongood argued that "no satisfactory basis for solving the problem whether the activity falls into one class or other has been evolved. The rules sought to be established are as logical as those governing French irregular verbs." "In a 1990 article that represents the most thorough and thoughtful work on this topic, Suffolk University Law Professor Janice C. Griffith observed that the "governmental/proprietary distinction has survived in the face of a barrage of scholarly and judicial attacks" because, "[1]ike so many other mechanical rules in local government law, the test provides the perfect mask for judicial balancing of competing equities and policies."”

The basic concept underlying the governmental/proprietary distinction is that municipalities act in different modes, i.e., sometimes as "governments" and sometimes "like businesses," and that their powers and their legal obligations should be treated differently depending on which of the two modes they are operating in. However, like many dichotomous legal constructs, the theory frequently disintegrates in practice. For example, state courts have variously held that a park is a governmental function ${ }^{4}$ and that it is not. ${ }^{5}$ Operation of a municipal solid

1. 2A Eugene McQuillin, The LAW OF Municipal Corporations $\S 10.5$, at 390-91 (3d ed. 2005 \& Supp. 2015) (footnotes omitted).

2. Murray Seasongood, Municipal Corporations: Objections to the Governmental or Proprietary Test, 22 VA. L. REV. 910, 938 (1936).

3. Janice C. Griffith, Local Government Contracts: Escaping from the Governmental/Proprietary Maze, 75 IowA L. Rev. 277, 317-18 (1990).

4. Fahey v. Jersey City, 244 A.2d 97, 100 (N.J. 1968) (“"[T]here is no indication that the playground facilities in question were operated for profit, for revenue, or for any reason other than to provide for the public health and welfare."); Etter v. City of Eugene, 69 P.2d 1061, 1062 (Or. 1937) (finding that a park is operated "exclusively for the use and enjoyment of the public" and "to promote the public health and welfare").

5. Augustine v. Town of Brant, 163 N.E. 732, 734 (N.Y. 1928) ("[T]he establishment of municipal playgrounds is in no sense a governmental function."). 
waste system has been treated as both "governmental"' and "proprietary." " Provision of city fire hydrants has sometimes been characterized as a "governmental" activity, ${ }^{8}$ sometimes as "proprietary", 9 and sometimes as both. ${ }^{10}$ Courts have characterized the construction and maintenance of public streets and traffic control devices as "governmental," 11 but they have also called that activity "proprietary" or "private." 12 In a 1911 case considering whether a city's solid waste

6. See, e.g., City of Spokane v. Carlson, 436 P.2d 454, 458 (Wash. 1968) (finding that a city solid waste system is governmental function "necessary for the comfort, safety, and well-being of the city"); Pruett v. Dayton, 168 A.2d 543, 544 (Del. Ch. 1961) ("Under the modern view, the disposal of garbage by a governmental subdivision involves a governmental rather than a proprietary activity, at least where zoning is involved."); see also United Haulers Ass'n, Inc. v. Oneida-Herkimer Solid Waste Mgmt. Auth., 550 U.S. 330, 342-43, 347 (2007); United Haulers Ass' $n, 550$ U.S. at 368-69 (Alito, J., dissenting) ("[A]ny standard "that turns on a judicial appraisal of whether a particular governmental function is "integral" or "traditional" is "unsound in principle and unworkable in practice." (quoting Garcia v. San Antonio Metro. Transit Auth., 469 U.S. 528, 546-47 (1985)).

7. See, e.g., Smoak v. City of Tampa, 167 So. 528, 529 (Fla. 1936) (“The difference between governmental and corporate duties is sometimes nebulous and difficult to classify, but there is certainly nothing connected with garbage disposal that partakes of a public or governmental function. It was, consequently, one of the proprietary or corporate duties for the negligent performance of which the city may be held liable."); Chardkoff Junk Co. v. City of Tampa, 135 So. 457, 461 (Fla. 1931) (holding that the city operated a garbage incinerator "for its quasi private corporate advantage"); City of Pass Christian v. Fernandez, 56 So. 329, 329 (Miss. 1911) ("[T]he hauling of dirt and trash is for the use and advantage of the city in its corporate capacity" and "for no governmental purpose.").

8. See, e.g., Stiefel v. City of Kent, 132 P.3d 1111, 1114 (Wash. Ct. App. 2006) ("The fact that the same water supply line serves both fire hydrants and the domestic water system does not convert a fundamentally governmental function into a proprietary one.").

9. See, e.g., Aschoff v. City of Evansville, 72 N.E. 279, 282-83 (Ind. App. 1904).

10. See, e.g., Lober v. Kansas City, 74 S.W.2d 815, 821 (Mo. 1934) ("[I]t is necessary in a particular case to distinguish as to which is the primary use and which the incidental use; and it may be necessary and proper to inquire, in reference to the particular negligent injury, as to whether the particular part or appliance of a waterworks system was devoted solely at the time or generally to a governmental function or to a corporate function, or whether the particular act in question was called for or caused by a governmental or a proprietary duty."); Miller Grocery Co. v. City of Des Moines, 192 N.W. 306, 307 (Iowa 1923) ("It is undoubtedly true that a municipal corporation can exercise its dual functions, governmental and proprietary, through the same agents and to a certain extent by the same instrumentalities.").

11. See, e.g., Kimmel v. City of Spokane, 109 P.2d 1069, 1071 (Wash. 1941) (finding that the regulation of traffic and parking is exercise of governmental police power); Rockingham Square Shopping Ctr., Inc. v. Town of Madison, 262 S.E.2d 705, 707 (N.C. Ct. App. 1980) (determining that the power to build and improve streets "is to be exercised in the discretion of the governing body of the municipality acting in its governmental, rather than its proprietary, capacity."); see also 10A MCQuillin, supra note $1, \S 30: 38$, at 445 ("The management of highways may be characterized as a municipal duty relating to governmental affairs.").

12. See, e.g., City of Seattle v. Stirrat, 104 P. 834, 836 (Wash. 1909) ("The power to grade streets, lay sewers or water pipes, and to lay the cost thereof upon abutting property is not a governmental or public function in the strict sense."); Wittorf v. City of New York, 15 N.E.3d 333, 337 (N.Y. 2014) (finding that a city employee's "act of closing the entry to vehicular travel was integral to the [street] repair job-a proprietary function"); Johnston v. City of East Moline, 87 
activities was more appropriately treated as "governmental" or "proprietary," the Supreme Court of Mississippi candidly stated: "It is a matter of no little difficulty to define what are and what are not purely governmental duties of a city. To a very large extent these questions can only be settled by the facts of each particular case, so variant are the conditions under which this question arises." 13 These words vividly underscore Griffith's comment that the governmental/proprietary distinction allows for fact-driven court decisions, serving as the "perfect mask for judicial balancing of competing equities and policies." 14 But the outcomes in those judicial decisions are extremely important to litigants because deeming an activity governmental or proprietary often determines, among other things, whether and how a municipality has the authority to act, whether an accident victim can recover against a local government, whether a contract with a locality is enforceable, and whether zoning regulations apply to construction of a new municipal facility.

A substantial reason for the confusion and for the shifting application of the governmental/proprietary categories is that besides the competing equities and policies, the governmental/proprietary distinction developed in several fields of law, each with its own set of rationales for treating a municipal activity as "governmental" or "proprietary." Judges have often quoted another court's conclusion that a particular local government service should be pigeon-holed in one category or the other, without looking at the original rationale and the original context. Further, because many different rationales were developed for identifying a governmental service as either "governmental" or "proprietary," it became easy for courts interested in specific outcomes to find a case with a rationale supporting the desired categorization of the service and thus the desired result. In her article, Griffith identified a half-dozen doctrinal rationales used in court decisions around the country: ${ }^{15}$

1. An activity is "governmental" either because it is an attribute of sovereignty or because its performance is "essential" or "necessary." This includes functions a municipality must perform for the survival and betterment of society, or the government can perform more efficiently or fairly than the private sector, or private enterprise will not undertake the job. ${ }^{16}$

N.E.2d 22, 27-28 (Ill. App. Ct. 1949) (maintenance of signals was a corporate function, not a governmental one).

13. City of Pass Christian v. Fernandez, 56 So. 329, 329 (Miss. 1911).

14. Griffith, supra note 3, at 317-18.

15. See id. at $305-16$.

16. See id. at 306. 
Attributes of sovereignty include the police power, the power of eminent domain, and budgeting and appropriation. ${ }^{17}$

2. An activity is "proprietary" because it has traditionally been performed by the private sector, such as providing water, electricity and gas. ${ }^{18}$

3. An activity is "governmental" because it has traditionally been performed by governments.

4. An activity is "governmental" because a state mandates that local governments perform it.

5. An activity is "proprietary" because its performance "primarily advances the interests of a local government." Related cases often speak in terms of a municipality acting "for its own advantage," like a corporation. ${ }^{19}$

6. An activity is "proprietary" where it involves providing services outside its geographic boundaries.

A recent Washington state case held that a city was authorized to impose excise taxes on another government - a public utility districtbecause the district was operating in a "proprietary" function. A concurring appellate judge in that case provided a somewhat different list of what he identified as the six (sometimes conflicting) tests that previously had been applied by courts just within that one state: ${ }^{20}$

1. A "governmental function" is performed for the common good of all, while a "proprietary function" is "for the special benefit or profit of the corporate entity."

2. A governmental function is based on a municipal corporation acting as an arm of the state, while a proprietary function is involved when a local government is administering local and internal affairs within its territory.

3. A public entity is proprietary when "it engages in business-like activities that are normally performed by private enterprise," while governmental functions are generally performed exclusively by governments.

4. Governmental functions involve performing activities for the public health, safety, and welfare.

19. See id. at 315.

20. See City of Wenatchee v. Chelan Cty. Pub. Util. Dist. No. 1, 325 P.3d 419, 431-32 (Wash. Ct. App. 2014) (Fearing, J., concurring). 
5. The purchase of a commodity "furnished for comfort by a municipality involves a proprietary function."

6. A municipality performs a proprietary function when it provides a service only to those who request it.

After expressing his frustration with the overlapping and inconsistent tests, ${ }^{21}$ that appellate judge quoted a 1958 New Jersey Supreme Court opinion to the effect that the governmental/proprietary "distinction is illusory; whatever local government is authorized to do constitutes a function of government, and when a municipality acts pursuant to granted authority it acts as government and not as a private entrepreneur." 22

This article will demonstrate that many of the doctrinal theories for the governmental/proprietary distinction break down in application. But proposals to completely jettison the distinction might go too far. This article suggests that there may be circumstances where something like a governmental versus proprietary analysis can be helpful. Most of the academic articles that have critiqued the distinction have addressed the issue in the context of just one doctrinal area or another. Griffith focused on local government contracting powers, ${ }^{23}$ and others focused on governmental tort liability, ${ }^{24}$ zoning, ${ }^{25}$ eminent domain, ${ }^{26}$ or adverse possession. ${ }^{27}$ Seasongood's 1936 article briefly mentioned several areas of law, ${ }^{28}$ with his greatest discussion concentrated on taxes. However, to comprehensively evaluate where the governmental/proprietary distinction may or may not make sense, one must drill down into each of the separate doctrinal areas where the distinction is applied. When we recognize the original rationales for characterizing municipal actions as "governmental" or "proprietary" in each of the separate fields - grants of municipal authority, government contracting, torts, eminent domain,

21. See id. at 431.

22. Id. at 433-34 (quoting Township of Washington v. Village of Ridgewood, 141 A.2d 308, 311 (N.J. 1958)).

23. See generally Griffith, supra note 3.

24. See generally Mary F. Wyant, The Discretionary Function Exception to Government Tort Liability, 61 MARQ. L. REV. 163 (1977).

25. See generally Note, Governmental Immunity from Local Zoning Ordinances, 84 HARV. L. REV. 869 (1971); James B. Sales, Comment, The Applicability of Zoning Ordinances to Governmental Land Use, 39 TEX. L. REV. 316 (1961).

26. See generally Note, The Sovereign's Duty to Compensate for the Appropriation of Public Property, 67 COLUM. L. REV. 1083 (1967).

27. See generally Paula R. Latovick, Adverse Possession of Municipal Land: It's Time to Protect This Valuable Asset, 31 U. MicH. J.L. REFORM 475 (1998).

28. Seasongood mentioned the governmental/proprietary distinction in connection with state expropriation of municipal land, liens on public property, basic municipal authority, contracts, torts, penalties, and taxation, but went into depth only in the area of taxation. See Seasongood, supra note 2 , at $930-38$. 
adverse possession, zoning, and revenue-we can better evaluate which, if any, of those rationales make sense and whether or not the distinction might play a useful role within that specific area of law.

This article analyzes each of the relevant doctrinal fields, and proposes that instead of abolishing the governmental/proprietary distinction altogether, local government powers should be conceptually realigned, with the "governmental" category divided in two. "Sovereign" coercive and policymaking powers like the police power, law enforcement, and the powers of taxation, eminent domain, budgeting, and borrowing should constitute a "governmental sovereign powers" category. Other general governmental services like schools, parks and roads, which represent "public goods" that are frequently paid for by taxes,${ }^{29}$ should be realigned with proprietary services that are rate-based "private goods" ${ }^{30}$ like electricity or water. This would create a broader category of "governmental service activities." In this article, the proposed new groupings are evaluated within the context of each of the seven substantive areas of law where the governmental/proprietary distinction has been used. The article argues that this realignment will produce more consistent legal analysis and suggests some of the key choices that legislators and judges would still have to make when deciding policies and cases involving the local government powers within each of the realigned categories.

Part I of this article recounts how the governmental/proprietary distinction has been used (and arguably abused) within each of seven categories:

- legislative grants of municipal authority

- government contracts

- torts

- eminent domain

- adverse possession

- zoning

- governmental tax exemptions

Acknowledging the wide variation nationally and the change in doctrine over time, Part I presents representative cases and the various rationales for the governmental/proprietary distinction within each category. Part II proposes the realignment of municipal activities so that

29. Economists define "public goods" as goods that benefit everyone more or less equally and cannot appropriately be charged to any particular group of "users." See JONATHAN GrUBER, PUBLIC Finance and Public Policy 169-89 (2d ed. 2005); David N. Hyman, Public Finance: A CONTEMPORARY APPLICATION OF THEORY TO POLICY 132-33 (11 th ed. 2014).

30. "Private goods" are defined and discussed in HYMAN, supra note 29, at 132-33. 
all of the non-law enforcement services are grouped with the "proprietary" services in the single category of "governmental service activities." Part III applies the realigned categories in each of the seven doctrinal areas where the governmental/proprietary distinction has made a material difference, and discusses the potential benefits of the realignment. Finally, this article provides a conclusion and recommendations going forward.

\section{DOCTRINAL AREAS USING THE GOVERNMENTAL/PROPRIETARY DISTINCTION}

This part reviews the key doctrinal areas in which the governmental/proprietary distinction has been applied. It is helpful to work through each category in turn. Only by taking the time to examine the history and application of the distinction within each doctrinal field can we understand why such a morass of conflicting decisions has evolved and how we might substitute the current approach with a more effective one.

\section{A. Legislative Grants of Municipal Authority}

The first doctrinal area in which we encounter the governmental/proprietary distinction relates to basic powers, i.e., whether or not a local government has been sufficiently authorized by state law to engage in an activity, and what auxiliary powers accompany the primary grant from the legislature. The generally accepted doctrine is that local governments have no inherent powers and derive all their powers from their states by constitutional or legislative grant. ${ }^{31}$ Although cities and certain other municipal corporations are frequently granted some type of "home rule," 32 the source of home rule powers is either a constitutional provision or a statute. ${ }^{33}$ Because of the enduring influence of John F. Dillon's 1872 treatise on municipal law, ${ }^{34}$ courts often have construed local government powers conservatively, searching for an express constitutional or legislative grant of authority for each activity

31. See Gerald E. Frug, The City as a Legal Concept, 93 HARV. L. REV. 1059, 1063, 1116-17 (1980); 2A MCQuillin, supra note 1, § 10:3, at 383-84; 1 ANTIEAU ON LOCAL GOVERNMENT LAW $\S 13.01$, at 13-3 (Sandra M. Stevenson ed., 2d ed. 2010 \& Supp. 2015).

32. See generally Dale Krane et AL., Home Rule in America: A FifTy-State HandBoOK 11 (2001).

33. See Richard Briffault, Our Localism: Part I-The Structure of Local Government Law, 90 COLUM. L. ReV. 1, 10-11 (1990).

34. John F. Dillon, COMmentaries on the LaW of Municipal Corporations (1872). See the discussion of Dillon infra text accompanying notes 51-55; see also Hugh D. Spitzer, "Home Rule" vs. "Dillon's Rule" for Washington Cities, 38 SeattLe U. L. Rev. 809, 814 (2015). 
engaged in by a local government. ${ }^{35}$ At the same time, once a source of authority has been identified, courts have often been comfortable extending more flexibility to the exercise of powers when they involve providing utility and other services that are of the sort commonly provided by the private sector. ${ }^{36}$ The idea is that if a local government is operating in a business-like mode, it should be able to make sensible business decisions without having to run back to the legislature for explicit permission. Examples include the following: implied permission to sign a contract creating a lien on agricultural property to which electrical power is extended, ${ }^{37}$ to set airport concessionaire fees, ${ }^{38}$ to sell photographs taken by city staff, ${ }^{39}$ to carry out the operations of a municipal electric utility, ${ }^{40}$ or to squeeze additional energy from existing resources by installing conservation devices in commercial properties. ${ }^{41}$ A century ago, the Sixth Circuit Court of Appeals stated succinctly:

The general rule is well established that, where a city is exercising governmental powers, it is closely limited, and clear authority for each such action must be found in the controlling general or special law of the state, but that, when it is exercising the rights of a proprietor in the management of its property, its council and officers resemble the directors and officers of a private corporation, and, in large degree, the powers of these agents and the responsibility of the city for their acts are governed by the rules applicable to private corporations. ${ }^{42}$

Further, without express statutory authority, the exercise of governmental powers (particularly the police power) is often limited to the area within their boundaries; ${ }^{43}$ but governments typically can operate

35. See 2A MCQUILLIN, supra note $1, \S 10: 3$, at 378-85.

36. See id. § 10:25, at 496-97.

37. See Hite v. Pub. Util. Dist. No. 2, 772 P.2d 481, 483 (Wash. 1989).

38. See Branson v. Port of Seattle, 101 P.3d 67, 71 (Wash. 2004).

39. See City of Winter Park v. Montesi, 448 So. 2d 1242, 1245 (Fla. Dist. Ct. App. 1984).

40. Mines v. Del Valle, 257 P. 530, 535 (Cal. 1927), overruled on other grounds by Stanson v. Mott, 551 P.2d 1 (Cal. 1976) ("That the powers of a city of a proprietary character are given a more liberal construction than those which are strictly governmental in character is settled beyond controversy by the decisions of our courts, and this rule is approved by our best text-writers.").

41. City of Tacoma v. Taxpayers of Tacoma, 743 P.2d 793, 800-01 (Wash. 1987) ("[W]hen the Legislature authorizes a municipality to engage in a business, "[it] may exercise its business powers very much in the same way as a private individual ...." (quoting Pub. Util. Dist. No. 1 v. Town of Newport, 228 P.2d 766, 771 (Wash. 1951) (second alteration in original)).

42. Audit Co. of New York v. City of Louisville, 185 F. 349, 352 (6th Cir. 1911).

43. See 2A MCQUILLIN, supra note $1, \S 10: 8$, at 402-08; 6A id. §§ 24:60, 24:61, at 243-52. 
in a proprietary capacity outside their geographical limits,${ }^{44}$ on occasion even when a similar proprietary governmental enterprise overlaps. ${ }^{45}$

Recognizing that there is wide variation in how courts have addressed the issue in different states, we can discern the underlying thinking that led to a frequent judicial determination to allow more flexibility in construing the scope of authority when local governments are carrying out business-like functions. Leading jurists and legal academics of the late nineteenth and early twentieth centuries were quite skeptical of government and were consumed with a fear that government at all levels would interfere with individual liberties ${ }^{46}$ and property, ${ }^{47}$ take sides in class conflicts, ${ }^{48}$ and damage the American economic engine. ${ }^{49}$ Key theorists included Thomas M. Cooley, Christopher G. Tiedeman, and most important here, judge and law professor John F. Dillon, who wrote the leading treatise on municipal law. "Dillon's Rule" asserted that municipal corporations possess only powers that had been "granted in express words, ... "those necessarily or fairly implied in, or incident to, the powers expressly granted, [and] those essential to the declared objects and purposes of the corporation." 51 These writers were concerned that when government exercised coercive powers, i.e., the regulatory "police power," 52 the power to seize private property by eminent domain, ${ }^{53}$ or the power to tax, ${ }^{54}$ the risks of arbitrary action were so high that built-in constraints were necessary. Thus, when exercising "strong" powers that might adversely affect rights or property, local governments needed to be constrained by being restricted to the specific

\footnotetext{
44. See Inc. Town of Sibley v. Ocheyedan Elec. Co., 187 N.W. 560, 564-65 (Iowa 1922); Schneider v. City of Menasha, 95 N.W. 94, 95-96 (Wis. 1903).

45. Normally, governments are prohibited from regulating or providing services within the same territory. See, e.g., S. Park Com'rs v. Chi. City Ry. Co., 122 N.E. 89, 91 (Ill. 1919). But the rule against two municipalities operating in the same territory has on occasion been held to apply only to governmental functions, not proprietary functions. See, e.g., Town of Newport, 228 P.2d at 771 (permitting town and public utility district to simultaneously provide electrical utility services within the same area); see also 12 MCQUILLIN, supra note 1, § 35:5, at 661-62.

46. See Thomas M. Cooley, A Treatise on the Constitutional Limitations which Rest Upon the Legislative Power of the StAtes of THE AMERICAN UNION 159-61 (1868).

47. See, e.g., John F. Dillon, Property-Its Rights and Duties in Our Legal and Social Systems, 29 AM. L. REV. 161, 175-76 (1895).

48. See Clyde E. Jacobs, Law Writers and the Courts: The Influence of Thomas M. Cooley, Christopher G. Tiedeman, and John F. Dillon upon American Constitutional LAW 26-27 (1954).

49. See generally David N. Mayer, The Jurisprudence of Christopher G. Tiedeman: A Study in the Failure of Laissez-Faire Constitutionalism, 55 Mo. L. REV. 93, 98 (1990).

50. Id. at 111-12.

51. DiLlON, supra note $34, \S 55$, at 101-02 (emphasis added).

52. Id. § 93, at 136.

53. Id. $\S \S 468-469$, at $452-53$.

54. Id. $\S \S 605-607$, at 576-78; COOLEY, supra note 46, at 235.
} 
powers clearly granted by state legislatures or constitutions. On the other hand, when municipalities reached into their corporate toolkits for devices to carry out responsibilities they had already been entrusted, or when providing services in a manner that did not threaten individual rights or property, there was less to worry about. A late edition of Dillon's treatise concluded that his rule of strict construction did not need to apply "to the mode adopted by the municipality to carry into effect powers expressly or plainly granted." 55

Ironically, the power that Dillon was most worried aboutregulatory "police power" - was and is an inherent and sovereign power of each state. ${ }^{57}$ It is the oldest area of governmental activity. ${ }^{58}$ It is a power that has been unequivocally granted to general purpose governments (e.g., cities and counties). ${ }^{59}$ Dillon recognized this and admonished that the power be applied only for the limited purpose of preventing people from acting or using their property in such a way as to injure others. ${ }^{60}$ Later legal thinkers and courts broadened the scope of the police power. ${ }^{61}$ But whether broad or narrow in its reach, regulation of human activities so that people can live peaceably remains the core "governmental" activity of general municipal government.

Because police power is an inherent governmental power that is necessary for the safety and order of successful communities, municipalities have been protected from liability for damages and losses incurred by private persons as a result of performing this important

55. 1 John F. Dillon, Commentaries on the LaW of Municipal Corporations $\S 239$, at 543 (5th ed. 1911).

56. Dillon, supra text accompanying note 47.

57. 6A MCQUILLIN, supra note $1, \S 24: 2$, at 14 .

58. Local government police powers stretch back to classical times. For example, ancient Roman municipal laws included strict land use, public health, and traffic control regulations. See, e.g., Law of Caesar on Municipalities and Charter of Urso, both enacted in 44 B.C., translated in Allan Chester Johnson, Et Al., ANCIENT Roman Statutes 94-95, 99 (1961). 6A McQuillin, supra note $1, \S 24: 2$, at 14 (McQuillin notes that the term "police power" goes back to the concept of the ancient Greek polis, or city, and notes that Blackstone defined the term "police power" to mean that which concerns "the due regulation and domestic order of the kingdom, whereby the individuals of the state, like members of a well-governed family, are bound to conform their general behavior to the rules of propriety, good neighborhood and good manners, to be decent, industrious and inoffensive in their respective stations.").

59. KRANE, supra note 32, at Appendix Table A10 (listing "City Public Safety" as a regulatory power that has been expressly vested in cities in 48 of the 50 of the states, and "City Public Health" as a regulatory activity similarly subject to home-rule powers in 27 of the states).

60. DiLlon, supra note 34, §93, at 135-36.

61. See Santiago Legarre, The Historical Background of the Police Power, 9 U. PA. J. ConsT. L. 745, $757 \mathrm{n} .70$ (2007) (Legarre describes the impact of Ernst Freund's more expansive view of the police power and the broader understanding of appropriate local government regulatory activity that took hold during the twentieth century.). See generally ERnSt Freund, THE POLICE POWER: PUBLIC POLICY AND CONSTITUTIONAL RIGHTS (1904). 
governmental function (such as enacting legal regulations that lead to private losses) or as a result of not performing this or another function because of budget constraints. Typical examples of this protection include court rulings that no local government liability arises from refusing to issue building permits, ${ }^{62}$ closing outdoor refreshment stands that caused congestion and disruption, ${ }^{63}$ destroying diseased trees to prevent the spread of pests, ${ }^{64}$ or failing to prevent the World Trade Center bombing from occurring. ${ }^{65}$ As discussed later, ${ }^{66}$ sovereign immunity, discretionary immunity, and related doctrines have historically shielded local governments from tort liability for actions in the exercise of their regulatory and their law enforcement powers. In Justice Robert Jackson's words, "it is not a tort for government to govern." 67

But, as noted above ${ }^{68}$ there is doctrinal confusion about whether municipal police powers are protected as "governmental" because they are "essential and necessary" to the community, because they are "for the common good," because they "protect public health and safety," because they are "inherent" and "sovereign," because they are carried out as extensions of state power, or simply because they have historically been performed by local governments. Whatever the reasons given, the doctrine remains that authority to carry out "governmental" tasks need to be expressly granted, and more flexibility is accorded when carrying out activities characterized as "proprietary" in nature.

\section{B. Government Contracts}

The distinction between "governmental" and "proprietary" functions of municipalities has also been significant in the area of government contracts-specifically with respect to agreements that might be said to "contract away" basic governmental powers. This is the area in which Griffith focused her critique of the governmental/proprietary distinction. As she carefully documented, early nineteenth-century courts were concerned about government contracts that would bind future legislatures and thereby short circuit the democratic decisionmaking process. ${ }^{69}$ There arose a doctrine that certain

62. See, e.g., Akin v. City of Miami, 65 So. 2d 54, 55 (Fla. 1953).

63. Belle Isle Grill Corp. v. City of Detroit, 666 N.W.2d 271, 274, 281-82 (Mich. Ct. App. 2003).

64. In re 14255 53rd Ave. S., 86 P.3d 222, 229 (Wash. Ct. App. 2004).

65. In re World Trade Ctr. Bombing Litig., 957 N.E.2d 733, 745-46 (N.Y. 2011).

66. See infra Part I.C.

67. Dalehite v. United States, 346 U.S. 15, 57 (1953) (Jackson, J., dissenting).

68. See supra text accompanying notes $15-21$.

69. See Griffith, supra note 3, at 286-90. 
governmental powers were "inalienable" and could not be ceded by contract. The most important of these inalienable powers was the police power. In Corporation of Brick Presbyterian Church v. Mayor of New York, ${ }^{70}$ an 1826 court held that despite a City of New York deed promising that a church could use a parcel of land as a cemetery, the deed could not abrogate the City's independent police power authority to prohibit burials as a public health matter. The court ruled that the church claim against the City was no different than if the City had been a private individual and a governmental body had imposed a health and safety regulation rendering the covenant useless. ${ }^{71}$ Although the United States Supreme Court had ruled earlier that the Constitution barred states from legislatively impairing contracts with or between private parties, ${ }^{72}$ the Court eventually accepted the Brick Presbyterian Church principle that the no-impairment clause did not block a proper exercise of the police power. ${ }^{73}$ State courts have consistently held that governmental regulatory functions could not be contracted away because regulation is so fundamental to what government (and only government) does, i.e., exercise "the power of self-protection on the part of the community." 74 Courts have ruled, for example, that a city cannot yield its police power control over the use of streets and parkways by franchise or contract, ${ }^{75}$ or agree not to exercise zoning powers. ${ }^{76}$

But the police power is not the only "governmental" function that courts have treated as inalienable and unalterable by the terms of a contract. For example, when a school district reneged on a decision to open an experimental high school in Kansas City, Missouri, advocates for the school brought an action for specific performance, arguing that an earlier school board decision created an enforceable obligation. The school supporters went so far as to suggest that operation of a school was proprietary in character. But the Missouri Court of Appeals held that although a municipal corporation may, by contract, limit exercise of its proprietary functions, it cannot limit its "governmental functions" and

70. See generally 5 Cow. 538 (N.Y. Sup. Ct. 1826).

71. See id. at $540-41$.

72. See U.S. CONST. art. I, § 10, cl. 1; Fletcher v. Peck, 10 U.S. (6 Cranch) 87 (1810).

73. Boston Beer Co. v. Massachusetts, 97 U.S. 25, 33 (1877) (“[T]he police power" extends "to the protection of the lives, health, and property of the citizens, and to the preservation of good order and the public morals. The legislature cannot, by any contract, divest itself of the power to provide for these objects."). See the discussion of this and related cases in Griffith, supra note 3, at 293-98.

74. See City of Akron v. Pub. Utils. Comm'n, 78 N.E.2d 890, 895 (Ohio 1948).

75. See Wills v. City of Los Angeles, 287 P. 962, 963 (Cal. 1930); State ex rel. Townsend v. Bd. of Park Comm'rs of Minneapolis, 110 N.W. 1121, 1123 (Minn. 1907).

76. See County of Volusia v. City of Deltona, 925 So. 2d 340, 345 (Fla. Dist. Ct. App. 2006); Red Dog Saloon v. Sedgwick Cty. Comm'rs, 33 P.3d 869, 871 (Kan. Ct. App. 2001). 
that if education were treated as a proprietary function "what possible function could be considered governmental?" In another case, the Minnesota Supreme Court held that city decisions about the ownership and management of public parkways, parks, and public grounds were "legislative," and the control of those decisions could not be limited on contractual grounds. ${ }^{78}$ As discussed in more detail below, basic powers necessary to support and implement municipal programs, like taxation ${ }^{79}$ and eminent domain,${ }^{80}$ are also frequently treated as being protected from constraint by contracts.

In contrast, when a local government operates in a "proprietary" capacity, its contractual arrangements are routinely treated as binding on its future decision-makers and future choices, just as they would be if the municipality were a private sector entity. For example, in Incorporated Town of Sibley v. Ocheyedan Electric Co. ${ }^{81}$ the Iowa Supreme Court held in 1922 that as a general matter a town could enter into a power sales contract with a nearby private electric utility, including energy prices effective for the life of the agreement. The court ruled that the municipal utility could

buy for the use of the municipality in the open market in accordance with its needs, and make binding and enforceable contracts for such purchases. It also may sell in the world at large such commodities belonging to the municipality as it may legally have a right and authority to sell. It is governed in its proprietary capacity by the same rules that govern private individuals or corporations. ${ }^{82}$

Similarly, Florida's Supreme Court in 1929 held that a city electric utility could commit itself to wiring private homes in order to encourage the increased use of electricity, noting that the city in that instance, was "operating and maintaining a public utility as more or less of a business venture, and the court should not interfere with the reasonable discretion of the properly constituted officers or authorities in the operation of such venture." ${ }^{83}$ A Washington state public utility district was permitted to enforce a contractual lien on a wholesale customer's property when that customer refused to pay its bill. Washington's high court wrote: "When

77. Coal. to Pres. Educ. on the Westside v. Sch. Dist. of Kan. City, 649 S.W.2d 533, 537 (Mo. Ct. App. 1983).

78. Townsend, 110 N.W. at 1124 .

79. See infra notes $172-184$ and accompanying text.

80. See infra notes 140-153 and accompanying text.

81. Inc. Town of Sibley v. Ocheyedan Elec. Co., 187 N.W. 560, 564 (Iowa 1922).

82. Id. at 563 .

83. Hamler v. City of Jacksonville, 122 So. 220, 221 (Fla. 1929).

84. Hite v. Pub. Util. Dist. No. 2, 772 P.2d 481, 483 (Wash. 1989) (quoting Puget Sound Power \& Light Co. v. Pub. Util. Dist. No. 1, 565 P.2d 1221, 1223 (Wash. Ct. App. 1977)). 
acting as a private business, a municipal corporation 'is implicitly authorized to make all contracts and to engage in any undertaking which is necessary to render the system efficient and beneficial to the public."'

There is an obvious logic to the broadly accepted principle that a local government should not be permitted to contract away its regulatory authority. The rule has sometimes been characterized as being necessary to protect the discretion of later democratically elected leaders. But at the same time, councillors who govern a city's electric utility will likewise have their discretion constrained by existing contracts, and those contractual constraints are widely permitted. The better rationale is simply that the police power, and the discretionary authority to adjust regulations as human environments and dangers evolve, must be preserved to protect public health and safety on a continuing basis. This understanding was stated clearly in Brick Presbyterian Church, ${ }^{85}$ the 1826 decision permitting the City of New York to impose a no-burials rule on a church that had purchased land for a graveyard from the City six decades before. In that ruling, the court noted that sixty years earlier the property had been outside the city's inhabited area, and "it never entered into the contemplation of either party, that the health of the city might require the suspension, or abolition of that right." held that it would "be unreasonable in the extreme, to hold that the [church] should be at liberty to endanger not only the lives of [the parishioners], but also those of the citizens generally, because their lease contains a covenant for quiet enjoyment." $" 87$

The courts have not restricted themselves to a dichotomy between the police power and proprietary powers; instead, the distinction has been drawn as governmental versus proprietary powers. The concept of "governmental" activity is much broader, and, as Griffith documented, concepts of essential "governmental" functions evolved and accreted over time. ${ }^{88}$ Eighteenth and early nineteenth-century city governments focused on public health and safety, i.e., the police power. ${ }^{89}$ However, over the course of the nineteenth century expectations of "governmental" activity increasingly included streets, waterworks, other public works, parks museums, libraries, zoos, and artistic displays. ${ }^{90}$ When the legal concept of limiting the contracting away of "governmental" powers was developed, the focus was on maintaining the police power and other

85. 5 Cow. 538, 542 (N.Y. Sup. Ct. 1826).

86. Id.

87. Id.

88. Griffith, supra note 3, at 320-21.

89. See Jon C. Teaford, The Municipal Revolution in America: Origins of Modern URBAN GOVERNMENT, 1650-1825, at 52-55 (1975).

90. Id. at 91-92, 114-15. 
powers that were unique to government. As the public's expectations of "governmental" activities evolved to include a wider range of public services, or as the privatization movement has reassigned delivery of some services back to the private sector, the legal doctrine stayed by and large the same, i.e., whatever is in the "governmental" powers box should not be contracted away, but powers in the "proprietary" box can be. In addition, as Griffith observed, assignments of activities to one box or the other that were developed in other fields of law, and the doctrines justifying those assignments, bled over into the analysis of what types of powers could or could not be contracted away. ${ }^{91}$ These include doctrines related to tort liability, condemnation, tax exemptions, and adverse possession-fields that Griffith did not analyze in detail. We will next focus on these other doctrinal areas and see how the use of the governmental versus proprietary distinction developed and caused considerable bewilderment in each of those fields - with confusion emanating from torts in particular, where the desire to compensate people in sorry circumstances stretched the boundaries of what are understood to be "proprietary" actions by governments.

\section{Tort Liability}

The governmental/proprietary distinction appears more often in tort cases than in any other field, typically when courts are considering whether or not a governmental entity should be subject to suit for allegedly tortious actions. There is considerable variation in how courts and legislatures have handled the governmental/proprietary distinction in the area of tort liability, and both the common law and statutes have altered the playing field within each state. The cases discussed below are meant to illustrate the challenges that judges and lawmakers have confronted when applying the distinction and to show how the labeling of municipal activities as either "governmental" or "proprietary" for tort law purposes affected the characterization of those activities in other areas of law.

\section{Sovereign Immunity}

The background issue is the common law doctrine of "sovereign immunity" of states from suit ${ }^{92}$ (at least for their "governmental"

91. Griffith, supra note 3, at 325-26.

92. A distinction is sometimes made between the "sovereign immunity" of states and the "governmental immunity" of their political subdivisions. 1 CiVIL ACTIONS AGAINST STATE AND LOCAl GOVERnMENT, ITS Divisions, AGENCIES, AND OfFicers $\S 1: 1$, at 1-3 to 1-6 (rev. $2 \mathrm{~d}$ ed. 2008 \& Supp. 2015). For simplicity, this article will refer to both doctrines as "sovereign immunity." There also exists a related doctrine, that governments are immune from statutes of limitations - at 
activities) and the related doctrines of discretionary immunity and public duty. Sovereign immunity in America has its roots in the English law concept that the King's own courts (or at least most of his courts) were without jurisdiction to entertain a lawsuit against the sovereign. ${ }^{93}$ This doctrine was accepted in the early American Republic without question and for many years maintained without thoughtful legal analysis. ${ }^{94}$ In 1869, two Supreme Court cases offered something in the way of a rationale, i.e., that, (1) without protection from a lawsuit, governments could not effectively perform their duties, ${ }^{95}$ and (2) "inconvenience and danger... would follow from any different rule." 96 Whether based on stare decisis, or a possible misunderstanding of English law, or unstated policy and financial considerations, nineteenth-century state courts, beginning with Massachusetts in $1812,{ }^{97}$ held that tort claims against municipalities for their "governmental" activities were available only in limited circumstances, if at all. The twentieth century witnessed a drive to circumscribe or eliminate the sovereign immunity doctrine because of its perceived unfairness to injured persons, ${ }^{98}$ and in many states the common law doctrine was rejected or sharply limited through legislative or judicial action, or both. As of 2002, the common law doctrine of sovereign immunity for local governments had been abrogated in at least thirty states. ${ }^{99}$ In most instances, judicial rejection of sovereign immunity was followed by statutes permitting it to continue for specific categories of government actions. ${ }^{100}$ However, prior to the elimination or

least when acting in their governmental rather than their proprietary capacity. See, e.g., City of Moses Lake v. United States, 430 F. Supp. 2d 1164, 1170-74 (E.D. Wash. 2006).

93. NAT'L ASS'N OF ATT'YS GeN., SOVEREIGN IMMUNITY: THE TORT LiABILITY OF GOVERNMENT AND ITS OFFICIALS 1 (1979).

94. Id. at $1-3$.

95. Nichols v. United States, 74 U.S. (7 Wall.) 122, 126 (1868).

96. The Siren, 74 U.S. (7 Wall.) 152, 154 (1868).

97. Mower v. Inhabitants of Leicester, 9 Mass. 247, 249 (1812).

98. The anti-sovereign immunity movement gained impetus from the publication of Edwin M. Borchard, Governmental Liability in Tort, 34 YALE L.J. 1 (1924) and subsequent articles by Borchard criticizing sovereign immunity. See NAT'L ASS'N OF ATT'YS GEN., supra note 93, at 5. More recently, the constitutional scholar Erwin Chemerinsky has argued that notwithstanding early Supreme Court acceptance of sovereign immunity, the concept is foreign to American notions of redress against government wrongs and should be found unconstitutional. See Erwin Chemerinsky, Against Sovereign Immunity, 53 STAN. L. REV. 1201, 1202 (2001).

99. 1 Civil actions Against State and Local Government, Its Divisions, Agencies, AND OFFICERS, supra note $92, \S 1: 9$, at 1-37 to 1-40.

100. Id. $\S 1: 11$, at 1-48 to 1-52. Judicial abrogation followed by adoption of statutes include, for example, Illinois (Molitor v. Kaneland Cmty. Unit Dist. No. 302, 163 N.E.2d 89 (Ill. 1959), followed by enactment of the Local Governmental and Governmental Employees Tort Immunity Act, $\S \S 1-101$ to 10-101, 1965 Ill. Laws 2982 (codified as amended at 745 Ill. CoMP. STAT. ANN. 10/3-108 (West 2015))); Missouri (Jones v. State Highway Comm'n, 557 S.W.2d 225, 231 (Mo. 1977), followed by adoption of Act of June 8, 1978, 1978 Mo. Laws 982 (1979) (codified as amended at Mo. ANN. STAT. $\S \S 537.600,537.610$ (West 2015))); and Indiana (Campbell v. State, 
modification of sovereign immunity in each state, judicial rulings often had already sliced "proprietary" activities from sovereign immunity's shield; the concept was that when governments acted like private sector actors they should be similarly liable for damages they caused. An early example from 1842 is Bailey v. Mayor of New York. ${ }^{101}$ New York City's water commission had constructed a dam in Westchester County for drinking water purposes. Negligent operation of the facility damaged the plaintiffs' properties, but when they commenced legal action, the water commission asserted that as a municipal body it was immune from suit. The court permitted the claim to proceed, outlining the distinction between a government acting in its "public" character and acting like a private entity:

[T] he distinction is quite clear and well settled, and the process of separation practicable. To this end, regard should be had, not so much to the nature and character of the various powers conferred, as to the object and purpose of the legislature in conferring them. If granted for public purposes exclusively, they belong to the corporate body in its public, political or municipal character. But if the grant was for purposes of private advantage and emolument, though the public may derive a common benefit therefrom, the corporation ... . is to be regarded as a private company. It stands on the same footing as would any individual or body of persons upon whom the like special franchises had been conferred. ${ }^{102}$

In its ruling the court reasoned that although a public entity, the water commission was similar to the private corporations that were routinely chartered in the first half of the nineteenth century to carry out projects of direct or indirect benefit to the general public, such as the creation of banks and railroads. ${ }^{103}$ At that time there was a porous boundary between public and private corporations, ${ }^{104}$ and the Bailey opinion noted that a private corporation rather than a city commission could readily have been chartered to provide drinking water to New York City; accordingly, there was no reason not to treat the City's water enterprise differently than an analogous private entity for tort liability

284 N.E.2d 733 (Ind. 1972), followed by enactment of Act of Feb. 19, 1974, Pub. L. No. 142, 1974 Ind. Laws 599).

101. See generally Bailey v. Mayor of New York, 3 Hill 531 (N.Y. Sup. Ct. 1842).

102. Id. at 539.

103. Id. at 543-44. For a discussion of the gradual shift from private or semi-private corporations for public benefit to private corporations for entirely private purposes, see BRIAN BAlogh, A GOVERnMENT Out of Sight: THE Mystery of NATIONAL Authority in Nineteenth-Century America 246-50 (2009); LaWrence M. Friedman, A History of AMERICAN LAW 188-201 (2d. ed. 1985); MORTON J. HorwitZ, THE TRANSFORMATION OF AMERICAN LAW 1780-1860, 109-14 (1977).

104. HORWITZ, supra note 103, at 113-14. 
purposes. ${ }^{105}$ The concept of tort liability for proprietary activities of government became a widely accepted doctrine, but the distinction between "public" or "governmental" activities on the one hand, and "private" or "proprietary" activities on the other, was never easily drawn. ${ }^{106}$ When courts desired to allocate damage to a local government entity, a frequent approach was to determine that the governmental defendant was acting in its "proprietary" capacity and thus could be held financially responsible. Nevertheless, there continued to be many instances where damaging governmental action or inaction was not subject to suit, ${ }^{107}$ including a recent example in In re World Trade Center Bombing Litigation, ${ }^{108}$ where the Port Authority of New York and New Jersey was held immune from suit for failure to provide sufficient security in a bombed parking garage because the Port Authority police were performing a "governmental" function. ${ }^{109}$ It is easy to accept that municipal electric, water, and certain other utilities are appropriately deemed "proprietary," 110 but there are many instances in which seemingly routine "governmental" activities were transformed into "proprietary" actions. These include the following rulings: that heirs of a drowned man could recover from a town because provision of a municipal park was not "governmental" owing to the town operating it

105. Bailey, 3 Hill at 540 .

106. 18 MCQUILLIN, supra note $1, \S 53: 70$, at 501-03.

107. See, e.g., Austin v. City of Baltimore, 405 A.2d 255, 259-60 (Md. 1979) (holding that the operation of a day camp where a child died is the governmental function of recreation, so no negligence action could be maintained against the city); Rankin v. Sch. Dist. No. 9, 23 P.2d 132, 133 (Or. 1933) (finding that a person injured by negligent operation of a school bus could not recover because the school district was operating in a governmental capacity); Maxmilian v. City of New York, 62 N.Y. 160, 160 (1875) (finding that the family of man run over and killed by an ambulance wagon operated by a city commission could not maintain suit because the commission was operating solely for public benefit); Ogg v. City of Lansing, 35 Iowa 495, 499 (Iowa 1872) (determining that the city's failure to disinfect the body of man who died of smallpox led to the death of his children, but in discharging "legislative and governmental" functions like public health, a city is "not responsible to individuals for a neglect or nonfeasance of its officers or agents"). For additional examples, see 18 MCQUILLIN, supra note $1, \S 53: 2 \mathrm{nn} .5-7$, at 158-60.

108. 957 N.E.2d 733 (N.Y. 2011).

109. Id. at 735. Another recent example is Crouch v. City of Kansas City, 444 S.W.3d 517, 524-26 (Mo. Ct. App. 2014), where a city firefighter's assistance in moving a disabled person was treated as a governmental, rather than a proprietary, service, so although the individual died as a result of the move, the city was immune from a wrongful death suit under the doctrine of sovereign immunity.

110. See, e.g., Junior Coll. Dist. v. City of St. Louis, 149 S.W.3d 442, 448 (Mo. 2004) (holding that a city engaged in a proprietary function when it operated the water system, even though the system was also used for firefighting); Peavey v. City of Miami, 1 So. 2d 614, 636-37 (Fla. 1941) (finding that a pilot who crashed into construction equipment on a runway could sue the city because airport operation is proprietary in character); Davoust v. City of Alameda, 84 P. 760, 762 (Cal. 1906) (determining that the wife of a pedestrian killed by a loose electric wire near a power plant could maintain an action because the city was clearly operating in a proprietary capacity). 
voluntarily rather than carrying out a mandatory duty for the benefit of the general public; ${ }^{111}$ that construction and maintenance of public highways was "proprietary" so the state was subject to a suit for an auto passenger's wrongful death; $;{ }^{112}$ that operation of a city auditorium was "proprietary" when an event held there was not strictly governmental in nature, and thus the family of a woman killed in the collapse of an adjoining platform could maintain an action against the city; ${ }^{113}$ and that a bicyclist injured when she hit a pothole negligently repaired by city personnel could recover because filling potholes is typically done by the private sector under contract so when city staff undertake the work they should be treated as operating in a "proprietary" manner. ${ }^{114}$

The desire to enable people to recover for serious injuries or death led many courts to develop new theories to stretch the definition of "proprietary" activities. ${ }^{115}$ One treatise puts it as follows: "In efforts to avoid the often harsh results occasioned by a literal application of the test, courts frequently created highly artificial and elusive distinctions...."116 While in most states the sovereign immunity doctrine was gradually limited by court rulings and statutes, ${ }^{117}$ other rulings had already muddied the governmental/proprietary boundaries and the language of these opinions - whether clear or confused-flowed into altogether different areas of municipal law where the proprietary/governmental distinction also made a difference, i.e., local government authority, contracting, and property ownership. In addition, as blanket sovereign immunity waned, there remained related concepts that shielded governments from tort liability for policy and resource allocation choices - the discretionary immunity doctrine and the public duty doctrine. These doctrines have demonstrated some resilience because of a widely held view that, as Justice Jackson stated, "It is not a tort for government to govern." 118 Understanding the discretionary immunity and public duty doctrines can assist in analyzing whether and when the governmental/proprietary distinction (or something like it) can make sense in the tort context. 98).

111. Augustine v. Town of Brant, 163 N.E. 732, 734 (N.Y. 1928) (citing Borchard, supra note

112. Smith v. State, 473 P.2d 937, 944 (Idaho 1970).

113. Chafor v. City of Long Beach, 163 P. 670, 674 (Cal. 1917).

114. Wittorf v. City of New York, 15 N.E.3d 333, 335, 337 (N.Y. 2014).

115. See the competing theories underpinning a "governmental" and "proprietary" distinction discussed supra text accompanying notes 15-20.

116. 1 Civil Actions Against State and Local Government, supra note 92, § 2:1, at 2-7.

117. See supra notes $98-100$ and accompanying text.

118. Dalehite v. United States, 346 U.S. 15, 57 (1953) (Jackson, J., dissenting). 


\section{Discretionary Immunity}

The concept of "discretionary immunity" of municipal governments was well-established by the time that Dillon published his treatise in 1872. He reported on a number of state cases holding that a "municipal corporation is not liable to an action for damages either for the non-exercise of, or for the manner in which in good faith it exercises, discretionary powers of a public or legislative character." ${ }^{119}$ As more state courts and legislatures abrogated blanket sovereign immunity, the discretionary immunity doctrine was often retained because of a recognition that certain activities can be effectively performed only by governments, in part because of the recognized inherent risks involved (such as law enforcement and fire suppression). ${ }^{120}$ Discretionary immunity was also built into the Federal Tort Claims Act of $1946 .{ }^{121}$ Although considerable litigation ensued regarding which decisions were at the discretionary "planning level" and which were at the nondiscretionary "operational level," "122 the concept of tort immunity for basic policy decisions stuck. A principal rationale for discretionary immunity has been separation of powers, i.e., that in our political system certain basic policy decisions are vested in the legislative and executive branches and that judical review of those decisions would be inappropriate. This rationale was voiced in 1968 by the Supreme Court of California ${ }^{123}$ and supported in 1980 by the United States Supreme Court in a civil rights case. ${ }^{124}$ There have been numerous opinions parsing out the scope and reach of discretionary immunity, distinguishing between "discretionary" and "ministerial" functions; ${ }^{125}$ determining whether government liability can arise only from actions analogous to

119. DiLLON, supra note $34, \S 753$, at 709 (emphasis added).

120. Wyant, supra note 24, at 164; see, e.g., 745 ILL. COMP. STAT. 10/2-201 (West 2015) ("Except as otherwise provided by Statute, a public employee serving in a position involving the determination of policy or the exercise of discretion is not liable for an injury resulting from his act or omission in determining policy when acting in the exercise of such discretion even though abused.").

121. 28 U.S.C. $§ 2680$ (a) (2012) (“Any claim based upon ... the exercise or performance or the failure to exercise or perform a discretionary function or duty on the part of a federal agency or an employee of the Government, whether or not the discretion involved be abused.").

122. Wyant, supra note 24 , at $169-70$.

123. Johnson v. State, 447 P.2d 352, 360 (Cal. 1968) (stating that there needs to be "an assurance of judicial abstention in areas in which the responsibility for [b]asic policy decisions has been committed to coordinate branches of government") (emphasis added).

124. Owen v. City of Independence, 445 U.S. 622, 648 (1980) ("For a court or jury, in the guise of a tort suit, to review the reasonableness of the city's judgment on these matters would be an infringement upon the powers properly vested in a coordinate and coequal branch of government.").

125. 1 Civil Actions Against State And Local Government, supra note 92, § 2:5, at 2-40 to $2-46$. 
private acts; ${ }^{126}$ deciding which legislative or judicial (or "quasi-legislative" and "quasi-judicial") functions are immune; ${ }^{127}$ and describing the policymaking or planning decisions that constitute the hallmark of discretionary immunity. ${ }^{128}$ But the bottom line is that government officials have to make policy choices vested in them without second-guessing from the judiciary-even when those decisions result in harm to someone, like budget choices that cut police or fire services ${ }^{129}$ or that omit potentially life-saving barriers from a highway improvement capital program. ${ }^{130}$

\section{Public Duty Doctrine}

Somewhat related to discretionary immunity is the public duty doctrine, which holds that when providing quintessentially governmental tasks such as police and fire protection or the enforcement of laws and ordinances, a government cannot be held liable in tort to an individual because the duty to provide that protection or enforcement is owed only to the public at large. ${ }^{131}$ Interwoven with the public duty doctrine is the idea that there is a lack of tort liability in the first place when governments simply do what they are supposed to do. This is particularly true in connection with the exercise of the police power and law enforcement. When government acts to protect the public, there can be uncompensated costs to individuals. For example, neither recoverable damage nor a taking is said to occur if a health department destroys diseased animals ${ }^{132}$ or infected trees, ${ }^{133}$ or if homes are destroyed to prevent the spread of a fire. ${ }^{134}$

126. Evangelical United Brethren Church of Adna v. State, 407 P.2d 440, 444 (Wash. 1965) (holding that the state tort claims act "does not render the state liable for every harm that may flow from governmental action, or constitute the state a surety for every governmental enterprise involving an element of risk").

127. Hargrove v. Town of Cocoa Beach, 96 So. 2d 130, 133 (Fla. 1957); Wyant, supra note 24, at $179-80$.

128. 1 Civil Actions Against State and Local Government, supra note 92, § 2:7, at 2-55 to 2-62; see, e.g., Carlson v. State, 598 P.2d 969, 972 (Alaska 1979) ("'[D]ecisions that rise to the level of planning or policy-making are considered discretionary acts which do not give rise to tort liability, while decisions that are merely operational in nature are not considered to be discretionary acts and therefore are not immune from liability.").

129. Campbell v. State, 284 N.E.2d 733, 737 (Ind. 1972) (noting, in a decision abrogating sovereign immunity doctrine, that governments cannot be liable for all acts or omissions that cause damage; for example, "one may not claim a recovery because a city or state failed to provide adequate police protection to prevent crime").

130. See, e.g., Avellaneda v. State, 273 P.3d 477, 480-81 (Wash. Ct. App. 2012).

131. 1 Civil Actions Against State AND Local Government, supra note 92, § 2:20, at 2-152 to 2-170.

132. Clark v. City of Draper, 168 F.3d 1185, 1188-89 (10th Cir. 1999).

133. In re 14255 53rd Ave. S., 86 P.3d 222, 225-26 (Wash. Ct. App. 2004).

134. Bowditch v. City of Boston, 101 U.S. 16, 18-19 (1879). 
Under the public duty doctrine, government is acting to protect and assist the general public. Accordingly, when government agents in good faith do not act, e.g., when city inspectors fail to identify a potential gas leak, ${ }^{135}$ a state agency does not inspect an amusement park ride, ${ }^{136}$ or a city does not maintain a fire hydrant, ${ }^{137}$ normally no duty is owed to an injured person because of the relevant government's inaction. The flip side of the public duty doctrine is that when governmental actors either purposely or inadvertently create a special relationship with the person who is subsequently injured, a "special duty" is created and the governmental entity may be held liable. ${ }^{138}$ The classic example is when a 911 operator assures a caller that "help is on the way" to the caller's house, a special duty arises, and the city might be held liable for failure to direct police to the correct address or to redirect officers when they could not locate the house. ${ }^{139}$ Although the public duty doctrine has been criticized as an unintended "backdoor version" of sovereign immunity, ${ }^{140}$ it continues to be applied in at least sixteen states ${ }^{141}$ with respect to "governmental" functions and is viewed as protecting state and local entities when they are doing what they are supposed to do. ${ }^{142}$

\section{Property Law}

Another area of law where the governmental/proprietary distinction appears is in the law involving property, specifically with respect to eminent domain, adverse possession, and zoning.

\section{Eminent Domain}

The exercise of eminent domain is an inherent sovereign power of the states, and, regardless of governmental or proprietary capacities, local governments in most jurisdictions exercise eminent domain only with a clear grant of authority from a state constitution or statute. ${ }^{143}$ Eminent domain is one of the "strong" governmental powers that local

135. O’Connor v. City of New York, 447 N.E.2d 33, 34-35 (N.Y. 1983).

136. Cormier v. T.H.E. Ins. Co., 745 So. 2d 1, 8 (La. 1999).

137. Gates v. Town of Chandler, 725 N.E.2d 117, 119 (Ind. Ct. App. 2000); Boyle v. Anderson Fire Fighters Ass'n Local 1262, 497 N.E.2d 1073, 1077 (Ind. Ct. App. 1986).

138. 1 Civil Actions Against State AND Local Government, supra note 92, § 2:21, at 2-171 to 2-177.

139. De Long v. County of Erie, 457 N.E.2d 717, 721-22 (N.Y. 1983).

140. Cummins v. Lewis County, 133 P.3d 458, 466 (Wash. 2006).

141. 1 Civil Actions Against State and Local Government, supra note 92, § 2:20, at $2-160$ to $2-162$.

142. Id. $\S 2: 21$, at 2-171 to $2-177$. It should be noted that the public duty doctrine has spawned an array of approaches focused on the breadth of public duty and types of actions that can cause a special duty to be created. Id.

143. 11 MCQUILLIN, supra note $1, \S 32: 11$, at 441-43, 32:59, at 704-06. 
governments normally cannot contract away. ${ }^{144}$ In condemnation law, the governmental/proprietary distinction comes into play mainly when the power of eminent domain is being brought to bear against local government property. In many states, whether the property is to be used in a governmental or proprietary mode makes a difference both in whether it can be condemned and in the level of compensation paid. The common law rule is that property held by a municipal corporation and used for a public purpose cannot be condemned for other public purposes absent express statutory authority, ${ }^{145}$ although many statutes do provide that authority. ${ }^{146}$ For example, in Village of Blue Ash v. City of Cincinnati, ${ }^{147}$ the Ohio Supreme Court held that a city could not, for a proprietary purpose (an airport), condemn another municipality's property that was already in use for a governmental purpose. ${ }^{148}$ This "prior public use" principle can also apply to attempts to condemn a piece of "governmental" land for a new "governmental" purpose, ${ }^{149}$ but the prior public use doctrine seems to have the most salience when protecting "governmental" property from condemnation for "proprietary" purposes. ${ }^{150}$

The governmental/proprietary distinction is most significant in determining the compensation paid to a local government when its property is taken. In many jurisdictions, a state can condemn municipal property held for a public use without paying any compensation whatsoever to the local government. ${ }^{151}$ The rationale is that when acting in a governmental capacity, local governments are acting on behalf of their states, and, absent a statutory requirement, nothing "prohibits the State from taking its creatures' property without providing

144. See, e.g., Home Bldg. \& Loan Ass'n v. Blaisdell, 290 U.S. 398, 435-36 (1934); W. River Bridge Co. v. Dix, 47 U.S. (6 How.) 507, 538-39 (1848).

145. 11 MCQUILLIN, supra note 1, § 32:79.3, at 790-92.

146. See, e.g., WASH. REV. CODE $§ 8.12 .030$ (2014) (authorizing cities to "condemn land and property, including state, county and school lands and property" for a wide variety of city purposes); GA. CODE ANN. § 20-3-58 (West 2015) (permitting condemnation of public property permitted for university purposes); see also 2 NiCHOLS ON EMINENT DoMAIN § 5:06[8], at 5-328 (Matthew Bender Elite Products 3d ed. 1997 \& Supp. 2015).

147. 182 N.E.2d 557 (Ohio 1962).

148. Id. at 561-62; see also City of Worthington v. City of Columbus, 796 N.E.2d 920, 924-26 (Ohio 2003) (The Ohio Supreme Court applied the same "prior public use" principle, ruling that one city could not condemn park land within its boundaries that was owned by another city in order to build a cemetery.).

149. See generally The Sovereign's Duty to Compensate for the Appropriation of Public Property, supra note 26.

150. See, for example, State v. Super. Ct. for Jefferson Cty., 157 P. 1097, 1098-99 (Wash. 1916) for the general principle that authority to condemn public land applies only to land held in proprietary capacity.

151. 1A Nichols ON Eminent Domain, supra note 146, § 2.27, at 2-142 to 2-147; $2 i d . \S 5: 06[8]$ at 5-328. 
compensation." 152 On the other hand, if a municipality holds land for a proprietary purpose, the state's condemnation of that property is treated as equivalent to condemnation of private land, and compensation must be paid. ${ }^{153}$ Further, when eminent domain statutes do require that governments be compensated for condemned "governmental" property, those entities will typically be paid a full "replacement cost" or "substitution cost," which is financially favorable to them. ${ }^{154}$ But compensation for the taking of property of a proprietary enterprise will be comparable to what a private property owner would receive, i.e., fair market value, which may or may not be sufficient to replace the asset. ${ }^{155}$ The governmental/proprietary difference in compensating for condemned public property has been criticized in part because the courts are inconsistent in determining whether an activity is best placed in the "governmental" or "proprietary" box, and in part because local residents with their "taxpayer" hats on are harmed by a state taking just as much as they are when wearing their utility "ratepayer" hats. ${ }^{156}$ One commentator argued cogently that if the state can seize a piece of municipal property without compensation, "it places an inequitable burden on a relatively small, discrete group - the citizens of the municipal corporation."157 Nevertheless, the distinction remains an active principle in the condemnation law of some states.

\section{Adverse Possession}

There is a widely applied doctrine that governmental property held for a public use is immune from adverse possession. ${ }^{158}$ The rationales include the concept that the legislature is unable to effectively supervise lands dedicated to public uses; ${ }^{159}$ that land held in trust for the public cannot be transferred without express legislative authorization; ${ }^{160}$ and that statutes of limitation do not apply to public uses. ${ }^{161}$ But in some

152. Comm'rs of Highways v. United States, 653 F.2d 292, 297 (7th Cir. 1981); see also The Sovereign's Duty to Compensate for the Appropriation of Public Property, supra note 26, at 1089.

153. See, e.g., City of Cambridge v. Comm'r of Pub. Welfare, 257 N.E.2d 782, 785 (Mass. 1970); Town of Winchester v. Cox, 26 A.2d 592, 594-95 (Conn. 1942); Village of Canajoharie v. State, 184 N.Y.S.2d 871, 872-73 (App. Div. 1959); 2 Nichols ON EMINENT DOMAIN, supra note $146, \S 5.06[8]$, at $5-329$ to $5-333$.

154. 5 Nichols ON EMINENT DomaIn, supra note 146 , $\$ 18.06$, at 18-37 to 18-39.

155. Id.

156. The Sovereign's Duty to Compensate for the Appropriation of Public Property, supra note 26, at 1097-98.

157. Id. at 1110

158. 10 MCQUILLIN, supra note $1, \S 28: 71$, at 445 . (listing examples from twenty-two states in which public use property is not susceptible to adverse possession).

159. City of Oakland v. Oakland Water-Front Co., 50 P. 277, 282 (Cal. 1897).

160. Montgomery County v. Md.-Wash. Metro. Dist., 96 A.2d 353, 357 (Md. 1953).

161. City of South Greenfield v. Cagle, 591 S.W.2d 156, 159 (Mo. Ct. App. 1979). 
states neither the legislatures nor the courts have made it clear that all public property, regardless of purpose, is so protected; in those jurisdictions, proprietary uses often are not treated as public uses, and proprietary property is susceptible to acquisition by adverse possession. For example, the Oregon Supreme Court held in 1931 that a city's water rights could be lost to a private property owner because the "power to provide a water system is not governmental or legislative in character, but strictly proprietary, and the city engaged in the prosecution of such an improvement and selling water for gain is clothed in such authority and subject to the same liabilities as a private person." 162 Similarly, New York courts have held that "land which is held by a municipality in its proprietary capacity is not immune from adverse possession."163 Courts have offered several justifications for treating "governmental" and "proprietary" property differently in connection with adverse possession. These justifications include the theory that only governmental property is held in a kind of trust, ${ }^{164}$ or that land held in proprietary capacity is not in "true governmental use" and should be accorded no more protection than private property unless a statute provides to the contrary. ${ }^{165}$ One commentator has cogently argued that "[r]egardless of the use to which the land is put ... it is an asset of the local government, [and] the current use of the land is irrelevant to its importance" to the public. ${ }^{166}$ However, the governmental/proprietary distinction continues to be actively applied with respect to the law of adverse possession.

\section{Zoning}

In a number of jurisdictions, municipalities are not themselves subject to the zoning regulations that apply to private property owners unless the legislature has determined otherwise. ${ }^{167}$ Zoning is an exercise of the police power; the traditional rationale for excluding governments from land use regulations is that "the state and its agencies are not bound by general words limiting the rights and interests of its citizens unless such public authorities be included within the limitation expressly or by

162. Ebell v. City of Baker, 299 P. 313, 318 (Or. 1931).

163. Casini v. Sea Gate Ass'n, 692 N.Y.S.2d 676, 678 (App. Div. 1999); see also Monthie v. Boyle Rd. Assocs., LLC, 724 N.Y.S.2d 178, 182 (App. Div. 2001); Ammirati v. Van Wicklen, 839 N.Y.S.2d 685, 689 (Sup. Ct. 2007).

164. Lewis v. Village of Lyons, 389 N.Y.S.2d 674 (App. Div. 1976).

165. Burbank v. Fay, 65 N.Y. 57, 72 (1875); Casini, 692 N.Y.S.2d at 678; Ammirati, 839 N.Y.S.2d at 689.

166. Latovick, supra note 27 , at $485-86$.

167. 8 MCQUILLIN, supra note $1, \S 25: 17$, at 69-71. McQuillin cites cases from twenty states supporting this basic proposition. In addition to zoning, the governmental/proprietary distinction can make a difference in the character and complexity of the environmental review process for a project. See, e.g., Weyerhaeuser v. Pierce County, 873 P.2d 498, 504-05 (Wash. 1994). 
necessary implication." 168 The concept has also been expressed in terms of governmental functions being "essential" and therefore exempt from zoning, ${ }^{169}$ or that the eminent domain power in effect provides governments with the authority to place their facilities wherever they choose ${ }^{170}$ Frequently, however, the zoning exemption for governments is not available if the relevant public property is held in a proprietary capacity. ${ }^{171}$ As in other fields of law, the governmental/proprietary distinction becomes a battleground as litigating parties press for favorable outcomes in their cases. Sewage treatment plants, ${ }^{172}$ solid waste facilities, ${ }^{173}$ and fairgrounds ${ }^{174}$ have all been deemed "governmental" rather than proprietary, and therefore the public properties involved were not subject to zoning requirements. In many of those instances the courts noted that the designation of the activities as "governmental" was a close call. Three commentators have noted the difficulties in distinguishing one function from the other and have suggested that either the courts or legislators should establish a presumption that all government land uses be subject to zoning restrictions absent statutory waivers or compelling circumstances. ${ }^{175}$

\section{E. Governmental Tax Exemptions}

Taxation is another "strong" power, inherent in the states and delegated by state constitutions or statutes to local governments. ${ }^{176}$

168. C.J. Kubach Co. v. McGuire, 248 P. 676, 677 (Cal. 1926).

169. Sales, supra note 25, at 322.

170. George R. Wolff, The Inapplicability of Municipal Zoning Ordinances to Governmental Land Uses, 19 SYRACUSE L. REV. 698, 700-02 (1971).

171. ROBERT M. ANDERSON, 2 AMERICAN LAW OF ZONING $\S 12.03$, at 480-82 (3d ed. 1986) ("The great difficult lies in determining which functions are governmental, and which are proprietary. The distinction is of ancient vintage, but it is neither clear nor stable .... [A] proprietary function of a municipal government of 1955 may become a governmental function in 1965."); see also Sales, supra note 25, at 322-23.

172. City of Scottsdale v. Mun. Ct. of Tempe, 368 P.2d 637, 639-40 (Ariz. 1962); Jefferson County v. City of Birmingham, 55 So. 2d 196, 200 (Ala. 1951).

173. Nehrbas v. Inc. Village of Lloyd Harbor, 140 N.E.2d 241, 243-44 (N.Y. 1957).

174. Book-Cellar, Inc. v. City of Phoenix, 721 P.2d 1169, 1171 (Ariz. Ct. App. 1986).

175. Governmental Immunity from Local Zoning Ordinances, supra note 25, at 879-80; Sales, supra note 25, at 328; Wolff, supra note 170, at 704-05, 713.

176. 16 MCQUILLIN, supra note $1, \S 44: 5$, at 23-27. The early Supreme Court held that a state could contract away its taxing power when its legislature has expressly declared its intent to do so. Providence Bank v. Billings, 29 U.S. (4 Pet.) 514, 560 (1830); New Jersey v. Wilson, 11 U.S. (7 Cranch) 164, 167-68 (1812). More than a dozen state constitutions contain express prohibitions on the reduction of taxing powers by contract: ALASKA CONST. art. IX, $\S 1$; ARIZ. CONST. art. IX, $\S 1$; HAw. Const. art. VII, $\S 1$; Ill. CONST. art. IX, $\S 1$; LA. CONST. art. VII, $\S 1$; MiCH. Const. art. IX, $\S 2$; Minn. Const. art. X, $\S 1$; Mo. Const. art. X, § 2; Mont. Const. art. VIII, §2; N.Y. Const. art. XVI, § 1; N.C. Const. art. V, § 2; OKLA. Const. art. X, § 5; WASH. Const. art. VII, § 1; see also Laurel Hill Cemetery v. City \& County of San Francisco, 93 P. 70, 74 (Cal. 1907), aff'd 216 U.S. 358 (1910) (holding that the local government taxing power cannot be contracted away). 
However, government property is itself widely exempt from property taxes on the theory that a tax levy would be necessary to pay the taxes imposed, thus taking money from one pocket and putting it in the other. ${ }^{177}$ Some state constitutions protect all forms of state and local government property from property taxation, ${ }^{178}$ while some others authorize the legislature to provide such exemptions. ${ }^{179}$ In one Florida case, local government property used for a race track was deemed proprietary and not public property and was therefore subject to tax. ${ }^{180}$ Excise taxes are often imposed on municipal activities. ${ }^{181}$ The federal government has long been permitted to charge excise taxes to states and their political subdivisions when engaged in proprietary enterprises. ${ }^{182}$ At the state level, statutes can cause the incidence of a tax to vary depending on whether the relevant activity is "governmental" or "proprietary" in character. ${ }^{183}$ For example, in Department of Treasury v. City of Linton, ${ }^{184}$ the legislature had imposed a gross income tax upon the income of every "person" engaged in a business activity. "Persons" included municipal corporations "engaged in private or proprietary activities or business." 185 The City of Linton argued that its water, gas, and electric utilities were governmental activities and thus tax exempt. ${ }^{186}$ The Indiana Supreme

177. 16 MCQUILLIN, supra note $1, \S 44: 72$, at 280 , $\$ 44: 80$, at 317 ; Seasongood, supra note 2, at 931 .

178. See, e.g., TEX. CONST. art. VIII, § 1(b); KAN. CONST. art XI, § 1(b); WASH. CONST. art. VII, § 1; FLA. CONST. art. VII, § 3(a); 16 MCQUILLIN, supra note 1, § 44:73, at 293-94.

179. See, e.g., ILL. CONST. art. IX, § 6; IND. CONST. art. X, § 1(a).

180. See Sebring Airport Auth. v. McIntyre, 642 So. 2d 1072, 1073-74 (Fla. 1994); see also Village of Watkins Glen v. Hager, 252 N.Y.S. 146, 150 (Sup. Ct. 1931); City of Providence v. Hall, 142 A. 156,158 (R.I. 1928).

181. 16 MCQuillin, supra note 1 , $\$ 44: 72$, at 287-89. For example, Washington State's sales tax statute includes in the definition of a "buyer" subject to the tax, any "municipal corporation, quasi municipal corporation, and also the state, its departments and institutions and all political subdivisions thereof, irrespective of the nature of the activities engaged in or functions performed." WASH. REV. CODE $§ 82.08 .010$ (3) (2014); see also CAL. REV. \& TAX. CODE $§ 6005$ (West 2015); Мich. COMP. LAWS $\S 205.51$ (2015).

182. South Carolina v. United States, 199 U.S. 437, 463 (1905). In Garcia v. San Antonio Metropolitan Transit Authority, 469 U.S. 528, 546-47 (1985), the Supreme Court rejected the extension of South Carolina's jurisprudence on "traditional" versus proprietary functions for determining whether a specific governmental function should be immune from federal regulation under the Commerce Clause. Justice Blackmun noted: "To say that the distinction between 'governmental' and 'proprietary' proved to be stable ... would be something of an overstatement." 469 U.S. at $541-42$.

183. 16 MCQuiLlin, supra note $1, \S 44: 74$, at 299-300. For example, Washington State's sales tax statute includes in the definition of a "buyer" subject to sales tax, "the state, its departments and institutions and all political subdivisions thereof, irrespective of the nature of the activities engaged in or functions performed, and also the United States or any instrumentality thereof." WASH. REV. CODE $\S 82.08 .010(3)$ (2014).

184. Dep't of Treasury v. City of Linton, 60 N.E.2d 948, 949 (Ind. 1945).

185. Id. at 949.

186. Id. at 950 . 
Court treated each of those enterprises as "a private and proprietary activity," and therefore the utility revenue was subject to an income $\operatorname{tax}^{187}$

In contrast, in King County v. City of Algona,${ }^{188}$ the Supreme Court of Washington held that while cities had been authorized by statute to impose gross receipts taxes on businesses, express statutory authority was necessary to impose excise taxes on a "governmental function," in this instance a county-operated solid waste transfer station. ${ }^{189}$ But in City of Wenatchee v. Chelan County Pubic Utility District No. $1,{ }^{190}$ a city's tax on a municipal electrical utilities revenue was upheld because the utility district was operating as the proprietor of a business rather than engaging in a "governmental" activity. ${ }^{191}$ A concurring opinion bemoaned the difficulties of distinguishing "governmental" from "proprietary" functions. ${ }^{192}$

In his 1936 article, Seasongood argued that "if a city deems it advisable and has the power to engage in a certain activity, so long as the activity is for a public purpose and does not offend against any constitutional prohibition, that effort, no matter how styled, ought to be free from the interference of taxation." ${ }^{193}$ However, the governmental/proprietary distinction has continued to be used in various tax contexts at the local government level.

\section{F. Mindless Application of Labels}

What frustrates people the most about the governmental/proprietary distinction is the tendency of courts to borrow the "governmental" or "proprietary" label from a case generated in a different field of law or from a different jurisdiction without thinking about (or explaining) whether the application of the label makes sense in the case at hand. This willy-nilly labeling of municipal activities is why Felix Frankfurter

187. Id. See also Colo. Dep't. of Revenue v. City of Aurora, 32 P.3d 590, 592 (Colo. App. 2001) (finding that sales tax can be charged to city when acting in proprietary capacity by renting golf carts); Dep't of Treasury v. Evansville, 60 N.E.2d 952, 954 (Ind. 1945) (holding that markets, wharfs, golf courses, airports, and cemeteries were "proprietary" and their revenues were subject to taxation); City of Lakeland v. Amos, 143 So. 744, 747 (Fla. 1932) (determining that business and occupation tax may be imposed on a municipal electric utility).

188. King County v. City of Algona, 681 P.2d 1281 (Wash. 1984).

189. Id. at 1283. But see Salt River Project Agr. Imp. \& Power Dist. v. City of Phoenix, 631 P.2d 553, 557 (Ariz. Ct. App. 1981) (holding that a city could not tax an irrigation project even though it was a proprietary enterprise, because irrigation was the primary function of the special purpose district).

190. 325 P.3d 419 (Wash. Ct. App. 2014).

191. Id. at 425 .

192. Id. at 431-34; see supra text accompanying note 20.

193. Seasongood, supra note 2, at 931. 
called the governmental/proprietary distinction the "quagmire that has long plagued the law of municipal corporations." 194 This practice is what leads to the operation of a public park being dubbed "proprietary" so the heirs of a drowned man could maintain a tort action against a city, ${ }^{195}$ while another case treats parks and parkways as "governmental" so that a city cannot enter into contracts limiting its future legislative choices regarding their operation. ${ }^{196}$ The same practice leads to a solid waste facility being labeled "proprietary" so that property owners could maintain a tort action against a city for careless operation of machinery that caused a fire, ${ }^{197}$ while another solid waste facility was treated as "governmental" and therefore immune from taxation by a city burdened with the costs of garbage trucks rumbling over its streets on their way to a transfer station. ${ }^{198}$

The lack of a rational basis for treating different government services differently for purposes of tort liability led many courts and legislatures to narrow sovereign immunity so that most municipal services were similarly vulnerable to damage actions. ${ }^{199}$ However, the earlier labels assigned to certain services outlived tort reform and continued to pop up in other areas of law, so that local governments might be constrained in making long-term promises concerning parks and roads (i.e., in the "governmental" domain), or barred from taxing a solid waste handling facility ("governmental") while being allowed to tax an electrical utility ("proprietary"). ${ }^{200}$ It may or may not make sense to permit cities to collect excise taxes from other governments that provide public services within those cities, but neither the rationale for a tax policy decision nor a rule on long-term municipal contracting bears much relationship to a rule on tort liability. Fundamentally, the governmental/proprietary distinction does not translate well between various fields of law.

194. Indian Towing Co. v. United States, 350 U.S. 61, 65 (1955).

195. Augustine v. Town of Brant, 163 N.E. 732,734 (N.Y. 1928).

196. State ex rel. Townsend v. Bd. of Park Comm'rs of Minneapolis, 110 N.W. 1121, 1123 (Minn. 1907).

197. Chardkoff Junk Co. v. City of Tampa, 135 So. 457, 461 (Fla. 1931) (stating that the city operated a garbage incinerator "for its quasi private corporate advantage").

198. King County v. City of Algona, 681 P.2d 1281 (Wash. 1984).

199. See supra notes $98-100$ and accompanying text.

200. Compare City of Algona, 681 P.2d at 1283, with City of Wenatchee v. Chelan Cty. Pub. Util. Dist. No. 1, 325 P.3d 419, 431-32 (Wash. Ct. App. 2014). 


\section{BACK TO THE FUTURE: A COMPREHENSIVE REALIGNMENT OF THE GOVERNMENTAL/PROPRIETARY DISTINCTION}

To make any sense out of the governmental/proprietary distinction we need to go back to its roots. Some have advocated for its eradication, ${ }^{201}$ or at least its expungement from certain areas of law. ${ }^{202}$ But we should not discount the original purpose of the concept just because lawyers and judges managed to make it so confusing over the course of two centuries. The underlying purpose of the distinction was simultaneously to protect and constrain the strong, coercive powers of municipalities, and to protect basic organs of democratic government. Those strong powers consisted, first and foremost, of the police power, plus the powers of taxation and eminent domain. These were the tools of regulation and the extraction of needed revenue and property. Dillon accurately reflected the attitudes of the late nineteenth-century legal establishment when he wrote that these powers were extremely important but that they needed to be granted sparingly and kept under control. ${ }^{203}$ When we review Griffith's and others' summaries of the rationales offered for the governmental/proprietary distinction, ${ }^{204} \mathrm{a}$ few (but just a few) of those explanations make sense today. These include the concepts that municipalities perform certain functions that are "essential" or "necessary" for the protection of public health, safety, and welfare (i.e., the police power) and for the survival and maintenance of common government (i.e., taxation, eminent domain, budgeting, and appropriation). Not coincidentally, these are the governmental powers that have been treated as "attributes of sovereignty." ${ }^{205}$ However, the fact that they have been labeled as sovereign powers does not per se make them eligible for special treatment. A major weakness of our common law is the sloppy use of labels and doctrines both by lawyers and by appellate judges who fail to review in each case the core reason for a doctrine and fail to thoughtfully evaluate whether that doctrine truly fits the situation. Sometimes judges prefer a mechanical test because it helps them justify the outcome they desire in a case while avoiding the hard analyses and the tough policy choices. But just because a service historically has been provided by governments is not a valid rationale for

201. See, e.g., Seasongood, supra note 2, at 910, 941-42.

202. See Township of Washington v. Village of Ridgewood, 141 A.2d 308, 311 (N.J. 1958).

203. See supra text accompanying notes $32-33$. It should be noted that when Dillon wrote his municipal law treatise in the late nineteenth century, local governments were engaged in delivering fewer services than they do today, and thus it might have been easier to apply the governmental/proprietary distinction.

204. See supra notes $14-21$ and accompanying text.

205. Griffith, supra note 3, at 306-07. 
labeling it "governmental" 206 and treating that activity the same as other traditional governmental functions like the police power. It is equally senseless to deem a local government activity "proprietary" solely because it has been performed frequently by the private sector ${ }^{207}$ without evaluating the qualitative differences between that activity and others. For example, electricity was initially generated and sold by the private sector $^{208}$ but within a few decades it was generated and sold by municipal utilities in many parts of the country. ${ }^{209}$ Does that make the provision of electricity "historically private"? And why should the government's provision of needed electrical power be treated differently in doctrinal areas such as breadth of municipal authority, or alienating powers by contract, or torts, or property law, than the provision of highways, which historically was more likely (but not necessarily) carried out by public agencies? ${ }^{210}$ Similarly, the fact that the state mandates that local governments perform a specific task ${ }^{211}$ does not tell us anything about why legal doctrine should treat that task as "governmental."

While there has been repeated and thoughtful criticism of the governmental/proprietary distinction, we should not lose sight of the fact that the police power to enact regulations, and the authority to carry out those regulations through law enforcement or code enforcement, are intrinsic governmental powers for a reason-we do not really want private enforcement of societal norms. Similarly, taxation, eminent domain, and budgeting are necessarily coercive powers (and solely public powers) that need to be both protected and constrained.

The approach recommended here is that for purposes of legal and policy analysis, the "governmental" powers category should be narrowed

206. See id. at 314.

207. See id.

208. The nation's first electric plant was privately developed in Appleton, Wisconsin in 1882, and a much larger electric power facility was privately built at Niagara Falls in 1896. The Introduction of Electrical Power, WIS. HIST. SOC'Y, http://www.wisconsinhistory.org/turningpoints/ tp-041/?action=more_essay [https://perma.cc/HL8A-D8SX].

209. In 1906, Congress passed the Town Sites and Power Development Act, which gave preferential rates for the sale of federally-generated electric power to municipal purposes. Pub. L. No. 59-103, 34 Stat. 116, § 5 (1906); Ben Tansey, Celebrating 100 Years of Preference, PUBLIC POWER (Oct. 2006), http:/www.publicpower.org/Media/magazine/ ArticleDetail.cfm?ItemNumber=17438 [https:/perma.cc/Q6D9-QRGB]. See also DAVID W. WILMA \& Walt Crowley, Power for the People: A History of Seattle City Light 22-31 (2010).

210. Toll roads and canals in late eighteenth and early nineteenth-century America were often developed by private or semi-private entrepreneurs or through what are characterized today as "public-private partnerships," although there was active advocacy for public development of major transportation infrastructure. See BALOGH, supra note 103, at 248-49; JOHN LAURITZ LARSON, INTERNAL IMPROVEMENT: NATIONAL PUBLIC WORKS AND THE PROMISE OF POPULAR GOVERNMENT IN THE EARLY UNITED STATES 88-89, 92-93, 218-20 (2001).

211. Griffith, supra note 3, at 314-15. 
to something close to its original definition, i.e., intrinsically governmental strong powers such as the police power, law enforcement, and the powers of taxation, eminent domain, and budgeting. All other government services should be lumped together, including (1) general services such as schools, roads, public transportation, fire protection, and parks, i.e., tax-funded public goods that were often (but inconsistently) placed in the "governmental" category, and (2) the fee-based "business-like" proprietary activities such as ports and airports, and the electric, water, solid waste, and sewer and storm water utilities. All of the activities described above are performed by local government, so the term "governmental" should not be assigned to just one group of powers or activities. The newly aligned categories could be called "governmental sovereign powers" on the one hand, and "governmental service activities" on the other:

\begin{tabular}{|l|l|}
\hline Governmental Sovereign Powers & Governmental Service Activities \\
\hline Police (Regulatory) Powers & Schools \\
\hline $\begin{array}{l}\text { Law Enforcement (police \& code } \\
\text { enforcement) }\end{array}$ & Roads \& Transportation Systems \\
\hline Taxation & Parks \\
\hline Budgeting, Appropriations \& Borrowing & Fire Fighting \& Life Safety \\
\hline Eminent Domain & Electric Power \\
\hline Legislative Policy Decisions & $\begin{array}{l}\text { Water, Wastewater, \& Storm } \\
\text { Water Systems }\end{array}$ \\
\hline & Solid Waste Handling \\
\hline
\end{tabular}

Corporate "toolkit" powers, such as the power to hire, train, and fire employees; purchase, sell, and lease property; and carry out public works, should not be placed in either category. They are simply what Dillon called the "mode" (i.e., tools) to carry out the substantive sovereign powers or service activities. ${ }^{212}$ Local governments have those tools either by implication from having been granted substantive powers ${ }^{213}$ or they can be expressly granted by statute. One can also think of taxation, eminent domain, budgeting, and borrowing as means to carry out substantive responsibilities, but they are strong corporate powers with a coercive element and they have always been regarded as inherent or "sovereign" powers of a state. Consequently, for analytical purposes they should be included in the list of "governmental sovereign powers."

212. See supra text accompanying notes $53-55$.

213. Id. 
The proposed realignment of local government powers is basically a functional approach, with the "governmental sovereign powers" matching what Griffith identified as powers that many courts had determined were inalienable by contract. ${ }^{214}$ Griffith critiqued the "function test" on the grounds that it works only when agreement exists as to which functions should go into which category, and because there remains a risk that judges will mechanically slot activities into a category without thinking about the underlying rationale. ${ }^{215}$ However, the existence of difficult interpretive issues in the application of a legal doctrine should not encourage people to drop that doctrine in its entirety. Indeed, if we could create analytical frameworks that were always easy to apply, we might not need judges at all. Griffith's recommended approach, which involves multiple balancing tests and judgment calls in the governmental contracting context, ${ }^{216}$ is likely to be as difficult to use as any other framework. Her standards for when a long-term municipal contract should be upheld include whether that contract "advances a governmental interest that outweighs the loss of governmental control," and whether that contract restrains governmental functions "no further than necessary." 217 These criteria are just as hard to apply as the various criteria that have been used to place a local government activity in the "governmental" or the "proprietary" box.

The key is to identify a fairly narrow set of governmental sovereign powers so that there is general agreement on the category. The regrouping of powers proposed in this article yields a limited category of governmental sovereign powers and a broad category of governmental service activities. Practical application of this division should not be such a tall order. By moving all government services into a single category, there will be very little opportunity for arbitrary assignments of an activity.

\section{APPLYING THE REALIGNED CATEGORIES TO DOCTRINAL AREAS WHERE THE GOVERNMENTAL/PROPRIETARY DISTINCTION HAS BEEN FREQUENTLY USED}

This section applies the proposed realignment in each of seven specific areas of law where the governmental/proprietary distinction has

214. Griffith, supra note 3, at 328-29.

215. Id. at 329-30.

216. Id. at 348-49. The practical problems with balancing tests in the context of zoning and the governmental/proprietary distinction are displayed in Laurie Reynolds, The Judicial Role in Intergovernmental Land Use Disputes: The Case Against Balancing, 71 MINN. L. REV. 611 (1987).

217. Griffith, supra note 3, at 348. 
been used. ${ }^{218}$ It suggests some of the key choices that lawmakers and judges would make when deciding policies and cases involving the local government powers within each of the realigned categories. In most areas of law, legislatures (not courts) are the best place for making the relevant policy decisions, whether those choices concern, for example, broadening tort liability for previously "governmental" services or protecting government property from taxation or non-compensated condemnation. However, both legislators and judges should benefit from looking at the policy and legal issues from an analytical perspective that groups the strong "sovereign" powers in one category and all the public services in another. ${ }^{219}$

\section{A. Applying the Realigned Groupings to Legislative Grants of Municipal Authority}

As described above, the traditional rule is that when a local government exercises "governmental" powers, its authority to engage in a substantive field of activity is limited and must be traced to a statutory or constitutional grant, but when a municipality acts in a "proprietary" capacity its powers are said to be broader and more flexible (at least once the underlying authority to engage in that proprietary activity has been granted). ${ }^{220}$ Confusion has arisen when different courts have shoehorned specific services like parks, fire hydrants, streets, traffic control, and solid waste handling in one category or the other, depending on the facts and the equities in specific cases. ${ }^{221}$ Instead, we could treat all services within the same category regardless of whether they are tax-funded public goods like parks and schools, or rate-funded services to

218. The seven areas of law discussed in this article are the main categories in which the governmental/proprietary distinction has been frequently used, but they by no means represent an exclusive list. For example, in addition to zoning, the governmental/proprietary distinction can make a difference in the character and complexity of the environmental review process for a project. See, e.g., Weyerhaeuser v. Pierce County, 873 P.2d 498, 504-05 (Wash. 1994). Another field is speech rights, where the distinction is significant when courts consider whether a government may appropriately use public financial resources to promote its positions on public issues.

In virtually all situations in which the government is acting in a proprietary capacity, rather than a regulator capacity, courts will relax First Amendment standards, on the theory that the government is free to enter markets as a participant, and when it does, the threat to free speech values is substantially less potent than when government exercises its police power to regulate the speech of others.

2 SMOLla \& NimMER ON FreEdom OF SPEeCH § 19:2, at 19-8 (2015).

219. It should be noted that in some circumstances the two categories of municipal activities may still overlap. For example, when a city condemns property for a new park it is exercising a coercive "sovereign" power to support a direct service activity., but these are still distinct types of power. Parks and recreation is a "governmental service activity," while the use of eminent domain is the exercise of a "governmental sovereign power."

220. See supra notes $29-40$ and accompanying text.

221. See supra notes $4-13$ and accompanying text. 
consumers like electricity, water, or sewer service. These services are similar in material respects. They are all needed and consumed by the public; they are provided by local government agencies because policymakers at one time or another decided that it made sense to have them governmentally provided; traditional public goods like parks are often tax-funded and "free" to users, but fees are often imposed for playfields, reserved picnic areas, and zoos. Further, while consumers have considerable discretion about whether and how much of a municipal utility service like electricity to purchase, the use of solid waste, wastewater, and storm water service is often mandatory even though those services are organized as "proprietary" utilities and funded through rates. ${ }^{222}$

In the context of determining whether the authority to provide these services should be strictly or flexibly construed, there is no logical reason to treat parks, streets, and schools differently from electric, water, and sewer service. One can legitimately argue that because of their coercive characteristics, local police power, taxation, and eminent domain powers (i.e., governmental sovereign powers) should require express constitutional or statutory authority, and the exercise of those powers should be tightly constrained. Dillon might have been right about this. But once basic authority exists for the delivery of government services of any kind, local governments should have considerable discretion and flexibility in how those services are provided. In the doctrinal area of legislative grants of municipal authority, replacing a "governmental/proprietary" test with a "sovereign powers/service activities" test would be helpful.

\section{B. Applying the Realigned Groupings to Government Contracts and \\ "Contracting Away" Inalienable Governmental Rights and Duties}

Griffith focused her excellent study on the analytical weakness of the governmental/proprietary distinction in the context of local government contracts - most importantly, agreements that might bargain away inalienable "governmental" powers. She persuasively documented how courts would label certain activities "governmental" without providing a careful rationale for doing so and how those activities would then fall into the "inalienable" category, thereby restricting the ability of a current government to enter into long-term contracts with respect to

222. See, e.g., WASH. REV. CODE $§ 57.08 .005$ (9) (2014) (The water-sewer district may compel property owners to connect to district's sewer system.); Teter v. Clark County, 704 P.2d 1171, 1176 (Wash. 1985) (Both city and county had authority to impose and collect mandatory storm water rates from upstream property owner regardless of whether he felt he was receiving a beneficial service). 
those activities because the contract might limit the future discretion of elected officials. $^{223}$

However, if we substitute a narrow category of "governmental sovereign powers" for the old "governmental" category, we find the issue of inalienable powers much easier to address and apply. We can restrict the items in the new classification to what Griffith called the "nucleus" of the traditional "governmental" classification: the powers of taxation, eminent domain, budgeting and appropriation, and the police power. ${ }^{224}$ These, along with law enforcement ${ }^{225}$ and discretionary policymaking, are the inherent (i.e., sovereign) powers of the states and their political subdivisions that most people expect should be under the control of elected officials - as the voters may change those officials from time to time. At the same time, by moving governmental services from the inalienable powers category into a new cluster with so-called proprietary powers, we are now able to treat parks, schools, and roads the same as water service, sewers, airports, and other services. Absent a constitutional or statutory prohibition, there would no longer be any question about the validity of a city council entering into a multi-year contract (with requisite consideration) to build and maintain a highway to assist a private development or to agree with a neighborhood to operate a swimming pool. These are simply governmental service activities, and municipalities could commit to providing those activities on a long-term basis in the same way that they can commit to providing water or electrical service to a private manufacturer.

\section{Applying the Realigned Groupings to Tort Liability}

The primary problem with the governmental/proprietary distinction in the field of tort liability is that courts frequently have shifted local government activities from the "governmental" box to the "proprietary" box to explain decisions that allow damage recoveries from municipalities. ${ }^{226}$ This is not to say that the plaintiffs should not have had an opportunity to receive damages, but the judicial practice of moving activities like parks, highways, auditoriums, and street maintenance from one box to another ${ }^{227}$ resulted in doctrinal inconsistency and confusion when the governmental/proprietary distinction was raised in later cases

223. Griffith, supra note 3, at 309-10.

224. Id. at 306-07.

225. For analytical purposes, it is helpful, though perhaps not necessary, to separate police power (the power to enact regulations necessary for the public health, safety, and welfare) from law enforcement, which is the enforcement of the regulations adopted by legislative exercise of the police power.

226. See supra notes $105-113$ and accompanying text. 227. See supra notes $110-113$ and accompanying text. 
involving the same activities but in a different field of law such as eminent domain, taxation, or government contracts.

The governmental/proprietary distinction no longer causes much trouble in the tort context within the many states that now allow damage actions in connection with most local government activities. But in the states where sovereign immunity has not been abrogated or replaced with a comprehensive statute prescribing where and when persons may bring tort actions against governments, ${ }^{228}$ the proposed realignment of municipal activities would be of substantial benefit. All government services would be treated the same for purposes of analyzing tort liability, whether the services are schools and parks (traditionally "governmental") or electricity and water (traditionally "proprietary"). Regulatory enactments under the police power would continue to be exempt from liability for damages, as would taxation and budgeting.

Recovery for losses from the exercise of one governmental sovereign power - eminent domain-would continue to be handled through constitutionally mandated compensation for takings. But there would be no distinction between municipal liability for negligent action or inaction in a park and picnic area operated by a city's parks department and liability for the same action or inaction in a park and picnic area adjacent to a hydroelectric dam that is operated by a public utility district (a "proprietary" entity). ${ }^{229}$ Discretionary immunity could remain in place with respect to legislative and high-level executive policy choices, as it has endured in many jurisdictions where sovereign immunity has been abrogated or substantially modified. ${ }^{230}$

Legislators and courts would still have to make difficult choices with respect to the public duty doctrine ${ }^{231}$ because the reclassification of a service such as fire protection from the traditional "governmental" category to the proposed "governmental service activities" category makes no difference in terms of the tort doctrine of public duty versus special duty. While any difference in the treatment of parks operated by cities versus those operated by municipal utilities is artificial, the distinction between a generalized public duty and a duty of care through a special relationship (special duty) is not artificial at all.

Judges and lawmakers will have to keep grappling with the public duty doctrine, but they will be required to do so based on what makes

228. See, e.g., supra notes $97-99$ and accompanying text.

229. For an example of parks, campgrounds, ballfields, and hiking trails operated by a public utility district, see Our Parks, Chelan COUNTY PUB. UTIL. Dist., http://chelanpud.org/parks.html [https://perma.cc/RV7H-KJF9].

230. See supra notes 119-120 and accompanying text.

231. See supra text accompanying notes $130-141$. 
sense from a policy standpoint rather than how an activity has arbitrarily been labeled. Further, because all local government services (other than law and code enforcement) would be grouped together, there will be an immediate reduction in the number of seemingly arbitrary court rulings based on the designation of a particular municipal service as "governmental" or "proprietary."

\section{Applying the Realigned Groupings to Property Law}

A realignment of local government activities between governmental sovereign powers and governmental service activities will help lawyers and judges when they analyze several issues related to municipal property and local government regulation of property.

With respect to state condemnation of municipal property, the proposed realignment would remove an artificial distinction that in some states has led to taxpayer losses when school, park, road, and other traditionally "governmental" properties were taken by state government without compensating local taxpayers. ${ }^{232}$ To the extent that common law courts are faced with the question, the proposed realignment would make judicial decisions much easier and would provide badly needed consistency. Under the approach proposed in this article, school, park, and road properties would be treated the same as utility, port, and airport properties. Presumably, but not necessarily, compensation would be paid for all municipal properties. A 1967 Columbia Law Review case note made a good argument that "the inhabitants of a municipal corporation often lose something when its property is taken. The fact of particularized loss should be sufficient to give a right to compensation to the unit of government." 233 Compensation to local taxpayers for condemned nonutility property, similar to compensating local ratepayers when utility property is taken, appears to be both consistent and equitable in terms of cost allocation. However, this is appropriately a choice for legislators.

The realignment of municipal powers would also provide consistency in the law of adverse possession of local government property, although it would not answer the underlying question of whether private sector persons should be able to acquire any public property through adverse possession. Under the approach proposed in this article, school, park, and road properties would be treated the same as utility, port, and airport properties. All those properties either would, or would not, be subject to adverse possession. Paula Latovick makes an

232. See supra notes $142-156$ and accompanying text.

233. The Sovereign's Duty to Compensate for the Appropriation of Public Property, supra note 26 , at 1119 . 
excellent argument that there are few, if any, good reasons not to protect local government property, regardless of its current use. ${ }^{234}$ Public property is public property. As Latovick observes, public lands are held in trust and it is not easy for governments to regularly inspect the large number of odd parcels that they acquire over the years. However, this is a question that ought to be handled by legislators. To the extent that it is addressed by courts, moving traditionally "governmental" property into a category with traditionally "proprietary" property might suggest that adverse possession of all public assets should be allowed.

In the law of zoning, as in condemnation and adverse possession, the governmental/proprietary distinction has caused doctrinal confusion, and treating all municipal properties alike will provide needed consistency. As in the fields of condemnation and adverse possession, legislators rather than courts are in the best position to make the policy call of whether local government zoning laws should apply to public properties. In some jurisdictions, local officials have handled the issue by expressly building public uses like fire stations and schools into residential zones. ${ }^{235}$ To the extent that courts have to address the question, there is practical merit to the proposal that all government land uses be subject to zoning restrictions absent express statutory waivers or special circumstances. ${ }^{236}$

\section{E. Applying the Realigned Groupings to Taxation and Tax Exemptions}

Immunity from taxation is another doctrinal area where the distinction between "governmental" services and "proprietary" services makes relatively little sense. The argument can be made that municipal properties that host tax-backed activities such as fire stations, schools, and roads should be exempt from property taxation because otherwise we would see revenue moving from one governmental pocket into another, and taxpayers being taxed to pay taxes. However, if one accepts that argument, then those activities should be similarly immune from excise taxes as well-but local governments are regularly forced to pay sales taxes when they purchase goods and services. ${ }^{237}$ To the extent that both property and excise taxation of municipal utilities are seen as appropriate because these "business-like" functions should pay their fair share of public services like roads, police, and fire protection, one legitimately can argue that traditional governmental activities (e.g., schools) also use

234. See supra text accompanying notes 27,166 .

235. ANDERSON, supra note $171, \S 12.04$ at $485-86$.

236. See supra text accompanying note 174 .

237. See supra note 181 and accompanying text. 
roads, police, and fire protection and that prudent cost allocation practices would charge a share of those services to the school district. Further, some "governmental" facilities such as golf courses and zoos operate as separate cost centers and charge user fees. Accordingly, shouldn't they be taxed the same as an electric utility? ${ }^{238}$ Alternatively, should all government functions be completely free from the interference of taxation, as Seasongood argued in $1936 ?^{239}$ After all, taxation of utilities is often seen as a mechanism to unfairly push costs of general government onto utility ratepayers because rates frequently are not subject to the types of constitutional and statutory limits that apply to taxes. $^{240}$

Many state constitutions provide local government with tax exemptions, particularly from property taxes. ${ }^{241}$ Nevertheless, legislatures retain a fair amount of discretion to tax or not tax local government property and activities. The realignment of activities that is proposed in this article takes the question of tax immunity out of the vagaries of judicial assignment or reassignment in the context of individual cases. All governmental services, property, and activities would be treated the same for property taxes and for excise taxes, respectively; it would be up to constitutions and statutes to specify, based on policy choices, which properties and activities deserve tax immunity.

\section{CONCLUSION}

The governmental/proprietary distinction has created substantial confusion among municipal lawyers and judges, principally because the original rationale for a "governmental" category became lost as the number of local government services expanded-both new services like schools and parks that were viewed as "governmental," and new utility services that came to be seen as "proprietary." The "governmental" services were grouped analytically with traditional inherent ("sovereign") powers such as the police power, law enforcement, taxation, and eminent domain. As a result, judges came to treat these

238. University of Florida Law Professor David M. Hudson has argued for broader and more consistent taxation of governmental property that is not clearly used for a clearly governmental purpose. David M. Hudson, Governmental Immunity and Taxation in Florida, 9 U. FLA. J.L. \& PUB. POL’Y 221, 263 (1998).

239. See supra text accompanying note 193.

240. See, e.g., Okeson v. City of Seattle, 78 P.3d 1279, 1285-86 (Wash. 2003) (Charging "rates" for streetlights improperly shifts costs of a general governmental function to utility ratepayers.)

241. See, e.g., Alaska Const. art. IX, § 4; ArIZ. Const. art. IX, § 2; Colo. Const. art. X, $\S 4$; Del. Const. art. X, § 3; Fla. Const. art. VII, § 4; IDAho Const. art. VII, $\S 4$; Ky. Const. $\S 170$; MinN. Const. art. X, § 1; NeB. Const. art. VIII, § 2; Nev. Const. art. 10, 1 ; N.C. CONST. art. V, § 2; N.D. CONST. art. X, § 5; WASH. CONST. art. VII, § 1. 
governmental services the same as the strong, coercive powers of local government when analyzing legal questions in a variety of rather different fields of law: municipal authority, contracting, torts, property, and taxation. Because of the all-too-frequent lawyer practice of grabbing a label from one court opinion that sounds like it might apply to a problem in an altogether different field of law, and because of the all-too-frequent judicial practice of accepting a label without digging into the underlying rationale to see if it really fits the case, there were scores of inconsistent decisions about whether a particular governmental activity was to be treated as "governmental" or "proprietary."

Not all of the difficult questions about municipal powers, tort liability, property, or taxation can be solved by the realignment of local government services as proposed in this article. However, the analysis and the outcomes are much more likely to be more consistent, and easier to analyze, if we group all governmental services together, leaving the strong powers in a category that resembles the original "governmental powers" category of the early nineteenth century. Just because an analytical concept is nearly two centuries old does not mean that it is outmoded. There were very good reasons for a New York court to rule in Brick Presbyterian Church $^{242}$ that the city of New York could not lawfully contract away its public health regulatory functions through a deed covenant.

There are good reasons for governments to be immune from suit for private losses resulting from legitimate land use regulations or legislative choices. ${ }^{243}$ However, the legal rationales for the early "governmental powers" decisions do not work well when they are applied in cases where the governmental/proprietary distinction is pivotal in determining whether or not a city might be liable in tort for an accident at a park versus a leaking dam or a highway, or whether a state can seize municipal property without compensating local taxpayers, or whether public property might be lost through adverse possession, or whether zoning does or does not apply to a new city hall versus a new public utilities building. Courts will have an easier time working through these issues if all the nonenforcement services of local government are realigned with the so-called "proprietary" functions for purposes of analysis in the future.

242. See supra text accompanying note 70. 